\title{
Incivility and danger: theorizing a Muslim undercaste in Europe
}

\section{Elisabeth Becker ${ }^{1}$}

Accepted: 25 April 2021 / Published online: 16 June 2021

(c) The Author(s) 2021

\begin{abstract}
Positing Muslim positionality in Europe as an undercaste helps to make sense of how cultural stratification, rooted in associations with incivility, has resulted in deep and unrelenting inequalities experienced by diverse Muslims. Based on two years of ethnographic research with a Muslim community in Berlin as well as a survey of secondary research, this paper both theorizes and empirically showcases the process by which Muslims have become synonymous with incivility, and how this affects opportunities and inclusion across the educational, economic, residential, and private spheres. By drawing parallels with other instances of caste-based status differentiation in the West, specifically the Jewish experience in Europe and Black experience in the USA, it further illuminates how cultural stratification through associations with incivility (as a modern secular coding of impurity) that endures for generations functions in the contemporary world. Employing the concept of caste deepens the cultural turn that has replaced economic or legal explanations of Muslim marginality in Europe. And it awakens a dormant sociological vocabulary that allows for a more precise theoretical understanding of this empirical social phenomenon and thereby the possibilities—and limits—of pluralism in modernity.
\end{abstract}

Keywords Muslims in Europe $\cdot$ Inequality $\cdot$ Caste $\cdot$ Pariah $\cdot$ Culture $\cdot$ Stratification

\section{Introduction}

Seated outside of the Şehitlik Mosque in Berlin, gazing out over a graveyard that divides the building from the street, Mustafa recalls his arrival in Germany in 1971. He wipes the sweat from his brow with the back of a callused hand, describing the guards who checked not only his Turkish passport but also his teeth at the border. Living in a barracks-like dormitory, with rows upon rows of

Elisabeth Becker

ax265@uni-heidelberg.de

1 Max Weber Institute of Sociology, University of Heidelberg, Bergheimer Str. 58, 69115 Heidelberg, Germany 
bunk beds in what was then West Berlin, Mustafa notes his sense of disorientation in a new city and a new country, everything — from the sights to the sounds-suddenly unfamiliar: an experience not of sensory deprivation, but disorientation. He could not speak or read in German, the signs and symbols of everyday life illegible. And he could no longer see the stars at night. A butcher trained in the köfte (Turkish meatball) houses set along the Turkish sea, he found work in a supermarket chain, quickly memorizing the German words for "brisket" (das Bruststück) and "shank" (der Schaft). Even after half a century had passed, Mustafa never came to terms with the fact that he was required in his new trade to handle the meat, muscles, and blood of pigs. After a disagreement with his boss over this aspect of his job one winter, he found himself locked outside of the supermarket warehouse, where his toes literally froze to ice. "I was treated like an animal," he explains, aged not by labor but by indignity into an early retirement.

Mustafa describes an experience of enduring cultural subordination in spite of advancing legal status in Germany, from migrant to permanent resident, and one reproduced across generations-his children and grandchildren citizens, yet still perceived as "below the Germans." Rhetorical categories of differentiation shifted from dehumanized labeling as workers to externalized labeling as ethno-national others (re-invoking the historical notion of "the terrible Turk") and then subordinated labeling as religious others ("the uncivil Muslim") throughout his nearly five decades in Berlin. Mustafa struggles, however, to pinpoint exactly what has prevented his full belonging, often citing "being Muslim," "my name," "where I came from," or simply, his voice trailing off as he repeats the words, "who I am, who I am."

Some social science scholars have come to explain this status of partial exclusion through subordination as stemming from economic inequalities (e.g., Wacquant 2006, 2007) or legal distinctions (e.g., Joppke and Torpey 2013), and in a recent cultural turn, largely Islamophobia (e.g.,Bleich 2011; Cakir 2014) or racialization/ cultural racism that targets Muslims (e.g., Meer and Modood 2009). In this paper, I too emphasize the cultural structures that create and maintain the subordination of Muslims in Europe, yet argue that employing the concept of caste-specifically that of undercaste-offers an opportunity to more fully capture, accurately name, and analyze the phenomenon at hand. Undercaste accounts for the functioning, hardening, and adaptation of divisive notions of cultural purity in modernity. Whereas Islamophobia centers on religion-based fear (Lopez 2011), and racialization/cultural racism on distinctive phenotypical or other visible markers (Allen 2005), undercaste accounts for the interlinking of biological conceptions of difference (blood-based) to those based on a Christian interpretation of religion, forging the impure-in European modernity's language, uncivil—status of Muslims in Europe (Nirenberg 2016).

Stratification research in sociology has long been dominated by class, driven by the notion that economic inequality creates and upholds other forms of social and cultural inequality (Alexander 2003). Classes and their resulting power arise out of "unequal access to material resources" and therefore differentiated standards of living (Saunders 2006, p. 20). Social theorists classify caste, on the other hand, as culture-based stratification. Castes, unlike classes, are a matter of ascription rather than achievement through education, experience, or economic attainment; they are hereditary forms of hierarchical stratification that people remain inside of no matter 
how much money they earn or capital they amass, with social closure summoned by status (Weber 1946; Bougle 1971; Dumont 1980).

As a sociological term, Max Weber operationalized caste not in the empirical plural (e.g., India has multiple castes within its caste system), but the analytical singular: that is, he sought to understand what happens when status is closed to an unusual extent, leading to the reproduction of a position of extreme marginality over time, such that people cannot get out of it no matter what class position they hold (Weber 1946). Building on this disciplinary precedent, contemporary sociologist Herbert Gans has notably used the terms caste and undercaste in his writings on urban inequality (Gans 1996). "Anyone economically or socially condemned to caste status will be viewed as different in skin colour or religion," writes Gans, "'Culture,' 'moral worth' or some other newly constructed characteristic can also be used to exclude people and place them in an undercaste" (Gans 1996, p. 151). While an undercaste status entails stigma, it is more than stigma, as it endures across generations, rather than easing over time; its reproduction, as seen in the second and subsequent generations of Muslims in Europe, makes it unique (Jodhka 2016, p. 229).

Postcolonial migrants and guest workers, many from Muslim majority societies such as Algeria, Morocco, and Pakistan (including what is today Bangladesh), began the sanctioned crossing of physical boundaries to Europe in the late 1950s. At the same time, guest worker programs instated to address post-WWII labor shortages spanned from 1945 to the mid-1970s, in countries such as Germany, Switzerland, Luxembourg, and Sweden, with Turkey a primary sending country (Castles 2006). Economic and social inequalities that persist into the second and third generations of these populaces today result from cultural distinctions attached to the abstracted figure of "the Muslim." Some have argued that the shift towards "Muslimness" as the key point of differentiation occurred with September 11th and other terrorist attacks in the Western world. But it began before this, with Muslim distinction replacing that based on ethno-national distinction inherent to the status of migrant or guestworker, as new postcolonial/postimperial populaces settled across Europe in the latter half of the 20th century (Schiffauer 2006).

Until Muslim migrants and their kin gained permanent residency and citizenship, Islam did not have to be accommodated, and could remain essentially externalized from European societies - at least in the public realm. Once it became evident towards the end of the $20^{\text {th }}$ century that large groups of Muslims were in Europe to stay, "the Muslim" rather than "the Turk," "the Maghrebi" or "the Pakistani" became perceived as the ultimate "Other" (Schiffauer 2006). Instead of the lifting or loosening of hierarchies in the second and subsequent generation as is often seen among post-migrant ethnic groups, hierarchies were hardened through this Muslim/ non-Muslim distinction, one that drew on cultural memories of early Muslim rule in Europe, ${ }^{1}$ as well as continuing geopolitical contentions between Europe and the

\footnotetext{
${ }^{1}$ In Mikaela Rogozen-Soltar's (2017: 12) ethnography of Granada, Spain, this memory is re-invoked in colloquial references to ethnically Moroccan residents as "moros" and "moras," a "slippery referent" that dissolves boundaries between "historical Moors" and Muslims in Spain, today.
} 
Muslim world (Alba 2005; Alba and Waters 2011). ${ }^{2}$ As migrants and post-migrants gained permanent legal status and political sway, Muslimness re-emerged as the forceful point of distinction in and for Europe, and one that has hardened into an undercaste.

In the sections that follow, I first engage with the scholarship on Muslim differentiation in Europe, subsequently analyzing how caste has been utilized to understand the systems of subordination that have placed both European Jews and Black Americans ${ }^{3}$ at the bottom of modern social hierarchies through their associations with incivility. I then provide a historical overview of the cultural process by which Muslims in Europe have become relegated to an undercaste status through their similar labeling with incivility, drawing on two years of ethnographic research with the Şehitlik Mosque community in Berlin, Germany. Finally, I trace overarching trends in education, the labor market, residential segregation, and intermarriage to show how incivility more broadly constrains social life, concluding with the questions that this raises about the limits of inclusion in Europe.

\section{Caste in conversation: the literature}

The idea of a Muslim undercaste emerges in conversation with a contemporary field of concepts employed to understand the subordination of Muslims in Europe, as even for the second and third generations, social and symbolic boundaries to the European mainstream remain (Norton 2013). In studies of postcolonial and guest worker settlement in Europe, some scholars have focused on class stratification, arguing that economic factors created and embedded the inequalities experienced by these populaces; Loïc Wacquant (2006, 2007), for example, emphasizes the role of class in enduring segregation patterns in France. Others, like Christian Joppke and John Torpey (2013), have instead centered on legal inequalities-specifically lack of citizenship - as fostering ongoing socioeconomic exclusions. Given that neither class mobility nor citizenship attained in the second and subsequent generations have translated into the full and equal inclusion of Muslims in Europe, however, social science scholarship has now largely turned towards cultural explanations of enduring inequalities. Jean Beaman (2017), for instance, shows how the children of North African immigrants remain "citizen outsiders" in spite of both economic saliency and legal belonging, as they are denied what she terms cultural citizenship in France.

\footnotetext{
${ }^{2}$ While sociologists have accounted for instances of "second-generation decline" into an underclass, they have not examined decline into an undercaste, again showing the dominance of economic over cultural measures of incorporation (Gans 1996; Portes and Zhou 1993).

${ }^{3}$ I use the terminology Black Americans, albeit recognize that from enslavement in the $17^{\text {th }}$ century to emancipation at the end of the $19^{\text {th }}$, Black people in the United States were not only excluded from citizenship, but dehumanized as chattel.
} 
Among culturalist perspectives, Islamophobia and racialization/cultural racism have risen in the 21 st century as the two dominant frameworks employed to understand Muslim marginality in Europe. At the turn of the century, the term "Islamophobia" (literally meaning "fear of Islam") arose as a leading conceptual attempt to capture the distinct cultural positioning of Islam and Muslims in the Western world. Islamophobia has been critiqued as suggesting intolerance rooted exclusively in religious rather than intersecting religious, ethnic, racial, and cultural distinctions (Lopez 2011). Responding to this critique by expanding its conceptual domain, Erik Bleich (2011, p. 1582) defines Islamophobia as "indiscriminate negative attitudes or emotions directed at Islam or Muslims." Even if understood in this etymologically detached way, the concept of Islamophobia faces the risk of reducing systemic inequalities to collective anxiety, a critique leveled by Esra Özyürek (2005). It cannot fully account for the origins, temporal and spatial development, ascriptive nature, and institutionalized socioeconomic implications of Muslims' negatively coded social status. It other words, Islamophobia explains the sentiments targeting Muslims in Europe, rather than a system of stratification that shapes their experiences, a limitation noted by Mikaela Rogozen-Soltar (2017) in her work on the politics of Islam in Granada.

Recognizing the limits of Islamophobia, many social scientists have come to examine the cultural subordination of Muslims through racialization and racism. Employing a stringent definition of racism, based on the physical expression of assumed biological difference, clearly does not fit the stratification of Muslims in Europe, as race, religion, ethnicity, and culture have all become signifiers of difference (Norton 2013). For this reason, racism in its narrow definition, as phenotypically based discrimination, has become expansively redefined vis-à-vis "cultural racism" by scholars like Christopher Allen, Nasar Meer, and Tariq Modood (Allen 2005; Meer and Modood 2009; Meer 2013). "While racism on the basis of markers of race obviously continues," Allen (2005: 49) writes, "a shift is apparent in which some of the more traditional and obvious markers have been displaced by newer and more prevalent ones of a cultural, socio-religious nature." The cultural racism/ racialization literature productively critiques the idea of "progress" by tracing the enduring nature of essentialized forms of difference in the modern world; it "shift[s] from a focus on product to process" (Brah, Hickman and Mac an Ghaill 1999, p. 4). In so doing, it illuminates the power dynamics that create such sociopolitical divisions, fixing the analytical gaze on those doing, rather than experiencing, othering. And it thereby exposes the state's deep investment in the citizen's body, contributing to a process that assigns "meaning to somatic characteristics" and produces "vicariously constructed phenotypes, (including prayer caps, beards)" as "corporeal shorthand for non-Christian difference" (Meer 2013, p. 388; Amin 2010, p. 8; Miles 1989, p. 75).

If the intellectual project is to make sense of the how and the why of the deep and lasting differentiation of Muslims, then the rich literatures on race should certainly be brought into direct conversation with empirical studies of Muslim life. Still, numerous challenges are posed by the blanket framing of Muslim stratification as a racialization process or racialized form. The idea of a postmodern "culturalist" "racism without race," as posited by Étienne Balibar, or that "religion" 
can simply "be raced," paradoxically modifies - if not erases-the very concept of "race" (while also downplaying the continuing importance of religious differentiation, as noted by Caner Dagli) (Balibar 1991, pp. 23-24; Dagli 2020). The resulting notion of a neoracism, cultural(ist) racism, countering biology "as the principle marker of difference," or "a racial logic that crosses the cultural categories of nation, religion, ethnicity, and sexuality," as, respectively, articulated by scholars like Balibar, Didier Fassin (2006), Nasar Meer (2014, p. 10), and Junaid Rana (2007, p. 148), alludes to a form of differentiation that requires another analytical vocabulary. That is, such adaptive and, again, etymologically imprecise conceptualizations loosen their connections to the concept employed; here the "racial" is transformed into an umbrella category to capture diverse and often dynamic forms of essentialization. Mayanthi Fernando (2014) makes this very critique in her work on the nexus of French laïcité and everyday Muslim exclusions, as she demonstrates how "Muslim" becomes the ultimate "Other" through a shifting, and yet intersecting, vocabulary of religion, culture, and race.

In this paper, I argue that the collective labeling of Muslims with incivility-vis a vis an entangled "knot" of religion, ethnicity, race, and culture-relegates them to an undercaste in Europe (Norton 2013). The secular modern understanding of impurity as incivility assigns Muslims an inferior status that has real and lasting consequences on social incorporation and economic achievement. It transcends stigmatization, as it entails a persistence and normalization of stigma attached to Muslim bodies and identities that endures across generations, and one experienced by diverse Muslim groups across Europe (Özyürek 2005). The experiences of my Turkish-German Muslim interlocutors described below, namely their exclusion as Muslims from notions of civility and civic life, is neither unique to ethnic Turks nor to Muslims in Germany.

Showing the diversity of associations made between Muslims in Germany and threat, Esra Özyürek (2014, p. 7) illuminates how white converts to Islam become perceived as "destabilizing" forces, unsettling boundaries built on collapsed ethnoracial and religious groupings; their choice of a subordinated status codes converts to Islam as threatening to the status quo, and therefore as uncivil. And the exclusion of Muslims as Muslims from associations with civility is further shared by ethnically and racially diverse Muslim groups-North African Muslims, as well as Pakistani and Bangladeshi Muslims in the UK, Turkish and Indonesian Muslims in the Netherlands etc.- - across Europe, and traced by scholars who work in these various contexts. ${ }^{4}$ Mayanthi Fernando (2014), for instance, explores the asymmetries of tolerance that continue to cast French Muslims as outside of the French national imaginary. Mikaela Rogozen-Soltar (2017) similarly describes the experiences of exclusion and subordination among "new Muslims" from North Africa seen as culturally external to modern Spain, albeit linked to the cultural memory of the Moors. And Paul Thomas (2014) argues that the almost exclusive focus of securitization on

\footnotetext{
${ }^{4}$ Examples abound in the work of Christopher Allen, Schirin Amir-Moazami, Jean Beaman, John Bowen, Mayanthi Fernando, Petra Kuppinger, Anna Kortweg, Nasar Meer, Tariq Modood, Esra Özyurek, Werner Schiffauer and Gökçe Yurdakul, among others.
} 
Muslims in the UK collapses ethnically, economically, and culturally diverse individuals into a singular and stigmatized Muslim collective.

Such incivility-based inferiority is, furthermore, not exclusively a contemporary European phenomenon. It has also been experienced by Black Americans, from enslavement to the "New Jim Crow," negatively constraining their lives-undercaste in another place. And it was experienced into the $20^{\text {th }}$ century by European Jews, conditioning societies to accept not only their exclusion but annihilation-undercaste in another time (Fredrickson 2002; Alexander 2012). As political theorist Anne Norton (2013, p. 228) powerfully asserts: "I see the Muslim question as the Jewish question of our time...the site where structures of hierarchy are anchored." While, over the course of a century, this so-called "Muslim question" has come to replace the so-called "Jewish question," it reveals enduring hierarchies in European societies (Norton 2013; Amir-Moazami 2016a, b).

\section{Caste in the west: from Europe's Judensau to Jim Crow America}

Numerous scholars have recognized the productive capacity of the concept of caste for better understanding enduring cultural distinction that fosters socioeconomic marginalization. They too have argued for its salience across temporal and geographical contexts. Caste has, for example, been employed to make sense of the experiences of European Jews and Black Americans, in which stigma hardened into a subordinate status enduring across many generations (Dollard 1937; Arendt 1944; Gans 1996; Davis, Gardner and Gardner 2009; Weber 2010; Alexander 2012; Wilkerson 2020).

Let us first turn towards yesterday's Europe, where the undercaste status of Jews became institutionalized when the Third Lateran Council of the Catholic Church determined that Christians should not live together with this religious group in 1179 . The Council subsequently enforced yellow head ornamentation to differentiate Jews from Christians (Ravid 1992). Thus, the color yellow-associated with the biblical downfall of Sodom and Gomorrah, burned by rain made out of sulfur and firebecame an external marker of Jewish impurity, enduring for over a thousand years, and reemerging in the yellow stars sewn onto Jews' clothing during the Holocaust (Kouwer 1949, p. 113). Another evocative symbol, the Judensau, appeared in thirteenth-century Germany and was soon inscribed on churches throughout Europe, including those in what are today France, Sweden, Belgium, Switzerland, and the United Kingdom (Shachar 1974). In 1543, Martin Luther famously commented on the Judensau sculpture on the Wittenberg State Church.

Here on our church in Wittenberg a sow is sculpted in stone. Young pigs and Jews lie suckling under her. Behind the sow a rabbi is bent over the sow, lifting up her right leg, holding her tail high and looking intensely under her tail and into her Talmud, as though he were reading something acute or extraordinary, which is certainly where they get their Shemhamphoras (Harvey 2017, p. 103). 
From the late Middle Ages until the end of the sixteenth century, Jews in Venice were relegated to the ghetto, perceived as impure, imbued with "mysterious polluting powers," disease supposedly spread by touching their "alien, seductive bodies" (Sennett 1994, pp. 215, 217). In the city's ghetto and beyond, virulent anti-Jewish sentiment transformed into anti-Semitism persisting far past the Middle Ages (Norton 2013; Sennett 1994). ${ }^{5}$ For centuries, Jews continued to experience social subordination across Europe, restricted in occupation, segregation that led to further ghettoization, regulation against intermarriage, and ultimately demonization, from the French Dreyfus affair that began at the end of the nineteenth century to the rise of Hitler and his policies of extermination (Fredrickson 2002).

In her writings from exile, Hannah Arendt (2007, pp. 74-75) argues that in spite of economic integration, Jews remained distinct in status as "a society outside of a society, a caste," "retain[ing] characteristics of a caste," and/or constrained by a "caste spirit" in modern Europe. She theorizes this particular differentiating "spirit" through the idea of the "Jew as Pariah"-pariah defined as "social outcast" or "members of a low caste," the word entering English by way of Tamil in the seventeenth century (Arendt 1944). ${ }^{6}$ Arendt (1944) was not the first to employ the word pariah-which she juxtaposed to the striving-to-assimilate Jewish "parvenu"-in order to make sense of the Jewish experience in Europe. Jewish French journalist and literary critic Bernard Lazare and Jewish poet Michael Beer used the term to describe Jewish social positionality in the early $19^{\text {th }}$ century (Wilson 1978, p. 144). In fact, in 1823 Beer linked the concepts of pariah and caste through his theater show Der Paria (The Pariah), in which a Hindu protagonist—an allegory for Jews in Europe-is denied full societal inclusion through a caste system (Traverso 1995, p. 43). Less than a century later, Weber (2010, p. 3), in an arguably derogatory text, similarly describes the Jewish experience as reflecting a caste status, due to Jews' "pariah existence," "separated formally or de facto from their social surroundings." Here it is relevant to note that Weber additionally portrays Jews as Gastvolk (guest people), invoking a discursive parallel with the subsequent status of Muslim Gastarbeiter (guest workers), that of partial inclusion, foreignness, and impermanence (recall Mustafa's words at the beginning of this text) (Momigliano 1980).

Across the Atlantic, in the post-slavery period prior to the Civil Rights Movement, Black Americans also experienced exclusion along caste lines, through institutionalized "racial mores" and a "one-drop rule" eerily similar to that of the Spanish colonists (Higginbotham 2013, pp. 36, 78). Here "incongruity" was shaped in terms of race. From the back of the bus to the poverty-stricken edges of urban centers, laws prohibiting everything from mixed-race bathrooms to mixed-race marriages, "blackness" transformed into a pretext for concurrent ordering and exclusion in the USA (Wilkerson 2020). The semantics of this category suggested white purity in

\footnotetext{
${ }^{5}$ I understand anti-Semitism here as the prejudice against Jews as a religious group, an ethnic group, and as the system through which Jews in Europe were racialized and made into a cultural whole based on the supposition of biological difference.

6 “The word comes in the 17th century from Tamil, '(hereditary) drummer,' from parai 'a drum' (pariahs not being allowed to join in with a religious procession)" (Knowles 2006).
} 
contrast to black pollution. In the American South, Jim Crow laws institutionalized the subordinate status of Black Americans, denying civil rights in everyday life (Fox 2007). In the worst cases, this led to the lynching of Black Americans by organized criminal groups sanctioned by authorities, most notoriously the Ku Klux Klan (Chalmers 1987; Christian 2005; Alexander 2012, p. 30). In his seminal 1937 work, Caste and Class in a Southern Town, John Dollard (1937) names this systematized exclusion based on indignity and blood impurity a caste. Allison Davis, Burleigh Gardner, and Mary Gardner (2009) echo this conceptualization in Deep South: A Social Anthropological Study of Caste and Class, based in Natchez, Mississippi, a community decisively ruled by Jim Crow. And historian Amy Louise Wood argues that violence against Black men permeating the American South in this period was not only racially motivated, but also justified as a religiously sanctioned act, "laden with Christian symbolism and significance . . ordained and consecrated by God" (Wood 2011: 48). Reflecting on these "religious rituals," journalist Jamelle Bouie (2015) concludes that "the God of the white South demanded purity."

In a piece titled "From Underclass to Undercaste," Gans (1996, p. 151) describes the positionality of Black Americans as long one of an undercaste, with "a racial connotation." "But there is nothing inherently racial about caste position," he cautions, instead arguing that it is through enduring cultural devaluation-attached not only to race but also other signifiers - that a group becomes relegated to an undercaste. Today, Michelle Alexander (2012) maintains that the prison industrial complex has forged a Black undercaste through a "New Jim Crow," set on purifying society through the mass incarceration of Black men in the USA (Alexander 2012). She defines this undercaste as "a group defined wholly or largely by race that is permanently locked out of mainstream, white society by law, custom, and practice" (Alexander 2012, p. 190).

Thinking about the Jewish experience in Europe and the Black experience in the United States in terms of caste reveals how cultural notions of "purity" and "pollution" become institutionalized in systems of hierarchy-whether in law, custom, or practice-justified through notions of religious, racial, ethnic, and/or cultural incompatibility (Alexander 2012, p. 20). As Mary Douglas (1966) argues, such pure/ impure distinctions serve to unify, and yet they do so through hierarchical divisions, that is by denigrating subsets of societies. Together, these cases allow us to see how the concept of caste can help us to understand the power of cultural differentiation in contemporary Western contexts.

\section{Impurity as incivility}

The hierarchies that condition and constrain Muslims' life opportunities today have been built on longstanding notions of impurity — coded as incivility in modernitythat collapse religious, ethnic, racial, and cultural distinctions. Such notions of impurity were used to justify the purging of Muslims and Jews from Europe during the Reconquista. Associations with incivility later emerged in colonial and imperial expansion, then extended through the negative cultural distinction of postcolonial/postimperial European Muslim populaces from the European mainstream. Here 
cultural memory coalesces with geopolitical configurations-from Umayyad rule to Ottoman-European antagonisms and colonial endeavors-that counterpose Islam and Europe (Said 1994).

During the Spanish Reconquista, a formative moment in the making of Europe, Christian leaders instated a social order based on blood purity (limpieza de sangre) to distinguish "Old Christians" from those tarnished by a single drop of Muslim or Jewish blood. Muslims who converted to Christianity were termed "Marranos," meaning both "faithless convert" and "filthy pig" (Malkiel 1948, p. 184; Eaude 2008, p. 44; Martínez 2008, p. 222). The Spanish extended this notion through colonial rule on the American continent, establishing a classification system (sistema de castas, system of castes) to rank mixed races, with the purer in blood (lighter, European-origin) superior to the more polluted in blood (darker-skinned Native Americans). Government officials in the colonies had to provide a "certificate of purity of blood," proving the complete absence of Muslim or Jewish ancestry (Martínez 2008, pp. 75, 83).

The notion of "civility" was born in the colonial metropolis, contrasted to the "otherness" constructed and emphasized in empire. It emerged as a mode of differentiation in (often Muslim majority) geographies seen as direct extensions of European states, from French Algeria to British India. Referring "to the standards of behavior and common measure - to the 'etiquettes, manners, and virtues' - that make public life coherent and hence possible," civility was utilized to establish and maintain hierarchical colonial/imperial relationships (Holston 2010, p. 53). In Civility and Empire, Anindyo Roy argues that civility was the very "ethos of the British colonial state," a "normative code" employed as "a means of imposing control and effecting exclusion" (Roy 2005). ${ }^{7}$ Cultural theorist Homi Bhabha moves from this spatially oriented critique to one of time as progress, that is a "Western nationalist discourse which normalizes its own history of expansion and exploitation by inscribing the history of the other in a fixed hierarchy of civil progress" (Bhabha 1994, p. 74).

Notions of incivility, as pollution in modern form, have thus been used to foster cultural stratification in plural, post-Enlightenment societies. With the Enlightenment both the geographic and temporal location of the so-called civilizing process, "uncivil," "unenlightened," "backwards," and "barbaric" have all risen as synonyms for the impurity of "the Other," in a discourse justifying ongoing subordination and violence in global projects of expansion. As an unforeseen consequence of such projects, immigration has historically placed new migrant groups into the category of the polluted/uncivil. While many such groups have become coded as civil through a purifying process (whether assimilatory or vis a vis expansion of the civil sphere, "a world of values and institutions" that "relies on solidarity"), others, like European Muslims, have not (Alexander 2006, p. 4).

\footnotetext{
7 For a robust analysis of the sociological conceptualization of civility and its relationship to Islam, see Armando Salvatore (2016). Salvatore (2016) suggests civility as a conceptual lens able to link knowledge and power in the study of Islam. He does so not by overlooking-but rather reformulating the concept to counter-some of its Euro-centric origins; by giving credence to the endogamous traditions of Islam and the Muslim world, he traces dynamic processes of civility that preceded colonialism.
} 
Recruited as guest workers into undesirable occupations in the post-WWII period, or "permitted" to migrate in the same era as subordinated citizens from colonized states, the undercaste status of Muslims today elucidates both the enduring afterlife of European empire and what Bhabha (1985) terms "sly civility": that is, for many, an unachievable dream of full inclusion. In Citizen Outsider: Children of North African Immigrants in France, Jean Beaman (2017) explores an "inegalitarian regime[] of citizenship" through the lived experiences of the children of postcolonial immigrants, revealing a deep and enduring cultural hierarchy that subordinates those cast as uncivil (Holston 2010, p. 51). With its "cultural conventions, everyday performances, aesthetic codes, and foundation narratives," civility thus upholds and extends the social hierarchy established in imperial projects through such "inegalitarian regimes of citizenship" across the continent in this postcolonial/postimperial era (Holston 2010, p. 51). Algerian-French sociologist Abdelmalek Sayad in fact describes not immigrants, but their children (at once embodying physical and cultural border-crossing) as "the height of both civil and political impoliteness, and the height of rudeness and violence towards national understanding" (Sayad 2010, p. 178). The child of the immigrant suggests the "Other" who cannot be expelled. Across the continent, Muslims are perceived as antithetical, and therefore dangerous to European liberal states; the threat of defilement makes something impure, the threat of disorder uncivil (Douglas 1966; Bauman 1991). The notion of Muslimsliving specters of Islamic dominion-as potentially unsettling the order of European modernity can be seen in many cultural forms, including citizenship tests, colloquially referenced as "Muslim tests," that seek to weed out conservative Muslims in countries like the United Kingdom, the Netherlands, Denmark, and Germany; and even the revocation of citizenship, as in the cases of imams publicly espousing antiLGBTQ sentiment in France (Löwenheim and Gazit 2009, p. 155; Fernando 2014).

Media accounts throughout Europe over the past decade and a half portray the wide-reaching implications of associating Muslims writ large with threat, with migration narratives increasingly couched in security terms; borders not only shut, but surrounded by barbed wire fences, manned by armed national guards (Baczynska and Ledwith 2016). The inflammatory words of French presidential candidate Marine Le Pen summarize this growing sentiment: "If it's about occupation, then we could also talk about it (Muslim prayers in the streets), because that is occupation of territory" (The Telegraph 2010). The late left-wing Jewish writer Ralph Giordano similarly called mosque building "a declaration of war," responding to the controversial erection of Germany's largest mosque in Cologne (Harris 2007). In this nowprevalent narrative, the foundational sources and figures of Islam come into question. Danish newspaper Jyllands-Posten famously portrayed the Prophet Muhammad as a radical with explosives in hand (McGraw and Warner 2012). Far right Dutch politician Geert Wilders termed the Prophet Muhammad a "terrorist worse than Bin Laden," and the Qur' an a "license to kill" (Cooper 2012; Bayraklı and Hafez 2016, p. 385).

Yet not only the far-right espouses essentialist visions of Islam and Muslims that perpetuate their associations with incivility. The claim that both Islam and Muslims are uncivil and thereby eroding Europe's sociopolitical fabric has been justified across the political spectrum through historic means (protecting hard fought for 
secular political systems, by the left), as well as contemporary renditions of divine will (protecting the [Judeo-] Christian history of Europe, by the right) (Van Bohemen and Kemmers 2011). Left and centrist politicians, jurists, and intellectuals have also painted the dangers of Islam in space and time, with Muslims portrayed as barbaric remnants of, threatening to pull Europe backwards into, a dark, irrational past. For instance, the centrist Cologne regional appellate court temporarily outlawed circumcision in Germany when it came under attack in 2012 as "violent" following complications from the procedure on a young Muslim boy (Yurdakul 2016, p. 77; Amir-Moazami 2016a, b). And leftist movements in France, Germany, and Switzerland fixate on complete relegation of religion to the private sphere, with the aim of producing a "neutral public sphere," by regulating public expressions of religion, most notably the headscarf (Özyürek 2014, p. 12; Özyürek 2005). French Communist parliamentary leader André Gerin sparked the debate that ultimately led to France's ban on the niqab, illuminating that a discomfort with Islam, and a resulting need to control it, cannot be deemed a politically marginal phenomenon (Davis 2011).

On the level of popular sentiment, a 2016 Pew Research Study shows anti-Muslim views rising across Europe (Wike, Stokes, and Simmons 2016). And in a German-, French-, and UK-based Gallup survey, Muslims are perceived as among the least desirable neighbors when compared to other groups, ranked above only drug addicts (Gallup 2012). Antipathy towards Muslims, Kristina Simonsen and Bart Bonikowski (2020) find, proliferates not only in European countries bound by ethnocentric nationalism, but also those bound by civic nationalism (i.e., Scandinavia). A powerful weaponization of this subordinated cultural status has recently gained momentum in Germany, where resident Muslims are blamed for rising levels of antiSemitism and Holocaust denial-arguably the worst of cultural crimes (Özyürek 2013). This perception of civic incompatibility vis a vis incivility also contributed to the decision of many to vote for Brexit in 2016, with the Leave Campaign espousing xenophobic rhetoric pointedly targeting Islam as eroding British society. In the aftermath of this vote, Muslims across the United Kingdom were cornered and confronted at an unprecedented rate, told to "get out, we voted leave!"; halal butcher shops burned to the ground; headscarf-wearing women spat on; and mosques threatened (York 2016; Yeung 2016; TellMAMA 2016).

Support of groups with xenophobic agendas has, in parallel, exploded over the past five years. Once marginal, if not marginalized, political "alternatives" now permeate mainstream politics. The initial frontrunner in Austria's 2016 presidential election, Norbert Hofer-who pledged to protect Austria against refugees and maintain its exclusively Christian identity - is one such case (Smale 2016; Postelnicescu 2016; Mocevic 2020). Far right-wing candidate Marine Le Pen similarly came in second in the French 2017 run-off for presidency (Stanley-Becker 2017). Le Pen gained popularity following her design of policy initiatives targeting Muslims, such as the "eat pork or go hungry campaign," which pressures schools to stop offering alternative meals to their students with religion-based dietary restrictions (Fraser 2015). Even former national "exceptions" to this institutionalization of the right are home to largescale anti-Islam parties. For instance, the far-right party Alternative for Germany (Alternative für Deutschland, AfD) garnered fifteen percent support 
in political opinion polls across Germany following its adoption of an anti-Muslim manifesto (Huggler 2016). While tens of thousands of individuals attended the infamous march of Patriotic Europeans Against the Islamicization of the West (Patriotische Europäer gegen die Islamisierung des Abendlandes, PEGIDA) in Dresden in January 2015, it is perhaps more telling that an opinion poll showed that one in three Germans back this movement (Deutsche Welle 2015).

The particular cultural impurity of the Muslim has evolved through the transformation of social taboo from "symbolically" to "literally injurious," relying on associations not only with dirt or pollution (first as "street sweepers" and today as uncivil denizens), but with direct threat to European survival (as potential terrorists) (Berreman 1960, p. 122). The emergence of Europe-which was also Christendom-in contrast to Islam, began with the Reconquista, but has been re-invoked in numerous places and times, both in terms of Christianity and secularity, from early modern European-Ottoman alliances to colonial subjugation and the postcolonial era (Asad 2002).

As Werner Schiffauer (2006) argues, the "enemy" is perceived as having moved back "within the gates" through the largescale postcolonial/postimperial migrations that brought thousands of Muslims to 20th century Europe, transgressing the at once geographical and imaginary borders between Islam/Muslims and Europe. Such transgression paradoxically resulted from Europe's own transgressions overseas. Just as paradoxical: civility as a colonial grammar of distinction that migrated, as lasting aftermath of empire, to the European core. The migration of this civil/ uncivil divide born in the colonies was potently embodied by the so-called Harkis, Algerian Muslims who served as soldiers in the French army defending the colonial state. Following migration from Algeria to France in the early 1960s, they were initially confined to "reception estates," in spite of their ultimate act of loyalty: fighting to preserve the French colony. In 1962, President Charles de Gaulle rhetorically extended the imaginary of the uncivilized Muslim in the colonies to the geographical terrain of continental Europe. "The term 'repatriates' obviously does not apply to the Muslims," he proclaimed (Shepard 2006, p. 231).

Today, nowhere is an association with incivility and threat more potent than the terror specter that dominates mainstream discussions of Muslims in Europe. This perceived entwinement of Islam/Muslims and violence evokes fears of unpredictability, irrationality, and willingness to risk life and limb; these fears are familiar, if not to individuals, to a cultural imaginary that has long posed Islam as an existential threat to Europe (Said 1994). And no one is exempt from this association at the heart of a narrative of looming demise, in which Muslims threaten to destroy Europe from the inside. From the halls of schools to the homes of converts, the pages of a book, schoolchildren, and a woman lounging on the beach, potential terrorists are feared to hide among us. In fact, the usual innocents-refugees, children-have become the nucleus of antiterrorism efforts in all of their nebulous forms. Journalist Emily Badger (2015) reports, "After the Paris attacks, you hear politicians equating Syrian refugees with terrorists. Of course, many of those refugees are fleeing the same terrorists Europeans fear. 'But it's a fact that they are Muslim,' says [Maarten] van Ham [editor of a book on segregation in Europe]." In a recent Pew report, those with anti-Muslim views were significantly more likely to associate refugees with 
terror and threat (Wike, Stokes, and Simmons 2016). Pew also found that the majority of Hungarians, Polish, Dutch, Germans, Italians, Swedes, Greeks, and Brits (those in eight of the ten countries surveyed) believe that the 2015 influx of refugees increased the likelihood of terror attacks (Poushter 2016). And across Europe, teachers in schools and universities are given the responsibility of identifying students at risk for radicalization. They must look for signs — a Qur'an, a headscarf — that a child increasingly identifies with Islam (Awan 2012). "Few things seem to scare the French as much as the sight of Muslim schoolgirls wearing head scarves," writes journalist Eduardo Cue (1994). These popular narratives at times collapse and at others shift between religious, ethnic, racial, and culture-based differentiation. And yet beneath these shifting signifiers of difference lies the shared premise of Muslim incivility, used to justify hierarchies of inclusion, and laying the ground for a Muslim undercaste. ${ }^{8}$

\section{Ethnographic insights: the repercussions of incivility}

I began this paper with a conversation between myself and Mustafa, who migrated half a century ago as a guest worker from Turkey to Berlin, and I will now return to that more granular level, drawing from two years of ethnographic research (across the period of 2013-2017) with the Şehitlik Mosque community in Berlin. This community predominantly consists of Turkish Sunni Muslims, and is part of a larger "revivalist" trend among the second and subsequent generations of Muslims in Europe, who are turning back to religious identities and practices (Jouili 2015; Parvez 2017). While the majority of my interlocutors are the children and grandchildren of immigrants, I additionally interviewed first generation immigrants and police officers in Neukölln, the Berlin neighborhood in which the mosque stands.

Since Muslimness rose as the point of differentiation from mainstream Europe towards the end of the 20th century, as settled guest worker and postcolonial populaces could no longer be cast as externalized migrants or ethno-national others, it follows that contention over Muslim belonging has come to center primarily on Islam. Osman, a social activist and one of my interlocutors at the Şehitlik Mosque, explained the shift that he experienced firsthand since he moved to Berlin from Turkey in the 1990s. In his office in Kreuzberg, a stark white room that contrasts with

\footnotetext{
${ }^{8}$ Why, one might ask, has an undercaste solidified in Europe but not the United States? The answer to this question is multifaceted, but includes: different historical constructions and memories (in the US largely by and against "Blackness" and in Europe largely by and against "Muslimness"); largescale Muslim migration to Europe in comparison to a much smaller Muslim populace in the US; relationality to migration, with the US perceiving itself as a migration country and many European countries (including Germany) resisting this status; and perceptions of religion, protected in public life in the US, albeit far more contested in many of Europe's secular states (Foner 2015). The absence of a Muslim undercaste in the United States does not, however, negate the securitization and discrimination against Muslims in the United States, nor does it negate the contributions of US foreign policy to sustaining Muslim distinction from the Western world.
} 
the lush green of trees outside the windowpanes, he tipped a coffee to his lips and shook his head.

Back in the day, people were yelling, "Turks get outta here!" Now they are yelling, "Muslims get outta here!" So, the segregation mechanisms have been altered; whereas in the past the segregation was based on ethnic refusal, now it's based on religious identity. So the negative connotation lies with the religion, more precisely, Islam. And Islam stands for a backward society, no human rights, no women's rights, honor killings, crime, no tolerance towards other religions, refusal of all other cultures, chauvinism, machoism.

With such virulent stereotypes attached to Islam, the regulation of Muslim bodies unsurprisingly focuses on visible symbols of "Muslimness." And what has long been termed a "politics of visibility" is also a politics of divisibility, as it deems some symbols, like the headscarf, the mosque, or the minaret, as outside of the purview of Europe's cultural borders (Allievi 2003; Becker 2017). The headscarf, in particular, deeply fused to the imaginary of the Muslim body as in but not of Europe, has dominated such juxtapositions in both European publics and politics, beginning in colonial/imperial projects and re-invoked in postcolonial/postimperial metropoles. In A Dying Colonialism, Frantz Fanon describes the unveiling of Muslim women in French Algeria, analyzing the veil as a universalized symbol of Islam's incivility, with its forced, public removal paradoxically justified as a civilizing act: a secular baptism into the European order. Joan Scott (2007, p. 81) describes the politics of the veil in Europe today as continuing this "civilizing process," with the unenlightened Muslim — often represented by the image of a veiled woman-juxtaposed not only to Frenchness but to enlightened Europe, as a whole.

In parallel with the permanent settlement of largely Muslim North African populaces at the end of the 20th century in France, the headscarf, deemed at odds with French secularism (lä̈cité), became banned in civic institutions, including for students in state schools. This constricted the public spaces in which Muslim symbols could be worn. While the headscarf debates that ensued soon after in Germany differed in their specific policies from those in France, regulating teachers rather than students in public schools, and justified through constitutional laws on state neutrality rather than laïcité, they have similarly centered on delimiting the Muslim body through its associations with incivility (Korteweg and Yurdakul 2014; Berghahn 2017).

In Germany, the bounds of such regulations were specifically determined by the Federal Constitutional Court (Bundesverfassungsgericht, FCC) in its 2003 and 2015 rulings, while enacted at the state level. In 2003, half of Germany's sixteen federal states instated headscarf bans for schoolteachers, with most soon amended as broader bans on all religious symbols, given that singling out the headscarf violates the constitutional principle of nondiscrimination. Notably, in many cases, these expanded regulations excluded Christian symbols, deemed historical and cultural, rather than religious (Elver 2012; Jones and Braun 2017). In 2015, the language of threat again came to characterize the Muslim body, with the FCC decision that such blanket bans also violated the constitution; they could only be upheld in cases where a teacher's donning of a religious symbol 
proved a "tangible danger" to state neutrality or school peace (Taylor 2017, p. 93). This ruling on the surface appeared to contend with discriminatory practices, but in fact reinforced both the interpretative ambiguity of headscarf bans and the broader bifurcating discourse of Muslim "danger" and mainstream "peace" in official state language describing the Muslim body.

It is not only its contestation in the legal realm, however, but also the various cultural grammars attached to the headscarf that affect the everyday lives of Muslim women across Europe (Hamel 2002; Fournier and Yurdakul 2010; Elver 2012; Korteweg and Yurdakul 2014). In 2010, Kubra Gümüsay, a Turkish-German columnist for Die Tageszeitung and Die Zeit, wrote:

No matter what I do, the Bio-Germans have made it clear that I will never belong to this country...I do not know under what circumstances, I as a human being with no German ancestry and a non-Christian religion could get a you-are-German seal...It was not always this way. Earlier I said as a matter of course, "I am German." Until a real German at the university responded, "Kubra, you're not German." "Why?" "Because you are wearing a headscarf." Aha. So that's it. That was a slap in the face. It was not the only one. And I realized that no matter what I do, I'll never be German.

The symbolic power of the headscarf to divide the Muslim body from the body of Germany also emerged in the stories of my interlocutors at the Şehitlik Mosque. For instance, when discussing the questions she encountered during the mosque tours she led each week, youth leader Tuba asserted,

A stupid question would be if I wear the headscarf in the shower, which people actually ask. Sometimes, I say yes. "What? You're really showering with a headscarf?" I find it's quite bizarre that they don't even get the joke and take it seriously or even entertain the idea that I would shower with a headscarf on.

Tuba reveals in this anecdote the disturbing depths of the headscarf's fusion with the Muslim body: merged with the image of the Muslim as vestibule of subversion, subordination, and strangerness. Gülay, a university student often found reading at Şehitlik, noted similar experiences regarding the symbolic power of the headscarf in public life.

I constantly encounter people who believe that I can't think, that I can't speak German because I am wearing a headscarf. I was once in the subway on my way back home from the university, an elderly lady was sitting next to me and she goes, "Can I sit here?" And I replied, "Most certainly." And she goes, "Oh, I thought you couldn't speak German."

Following this conversation with Gülay on a late autumn afternoon in 2014, I boarded the bus from Şehitlik with Yusuf, a law student and youth leader at the mosque. In colorful language, he painted the picture of a woman on the street, hand wrapped around a dripping ice cream cone-or rather two women, one his mother and one me. In his powerful description of a potential encounter, Yusuf 
posited the different reactions that this scene would evoke depending on the simple presence or absence of a headscarf. "It's like, for example, when you would walk on the street and eat ice cream and drip on the ground-people wouldn't say anything. But if my mom would do that with her headscarf, people would say, 'Don't you see what Muslims do?',

My interlocutors described not only the fraught representation of the headscarf in public life, but also overt and covert pressures to remove it, with Sadiye, a young artist in Berlin, relating her own process of unveiling. Sadiye recounted how customers in the supermarket where she worked in high school berated her, one even spitting at her, sometimes explicitly mentioning the presence of her headscarf. Eventually, she removed the scarf, both exhausted by such ostracism and fearing professional failure. Yet Sadiye lamented that this act did not entirely erase the discrimination she faces in her everyday life, such as struggling to find a rental apartment with a "Muslim-sounding name"-an experience echoed by many of my interlocutors. As in the French colonies (the unveilings, the Harkis, who remained first and foremost "Muslims") one can never fully overcome the European branding, in both senses of the word, of Muslim bodies with incivility. Here the person underneath the controversial cloth, still Muslim without it, remains degraded. That is, exposure, nakedness, nothing forgives the Muslim her Muslimness.

Visibly Muslim bodies, systematically marked with incivility, are further disciplined in public life, beginning with early education and continuing throughout adulthood in widespread surveillance. Nora, an engineering student, spoke of experiencing such discipline during her elementary school experience. "I decided to wear a headscarf, but my mom didn't want me to. She had so many bad experiences, and she took hers off. What happened was, I failed gym because I wouldn't take off the headscarf in class." Even though she participated in all requisite activities, Nora's gym teacher failed her when she refused to take off the headscarf, claiming that it "endangered" her well-being, illuminating the unbound power of a securitized discourse, officially upheld by the FCC. This very personal experience reflects a larger debate over religion-based exemptions from school activities, a subject of numerous lawsuits by Muslim families, and deep social contention, through mainstream associations with female oppression in Germany. In 2016, the FCC ruled that all girls must participate in swimming alongside of boys at school (Deutsche Welle 2020). Here the civic disciplining of the child's body through sports, including a culture where undressing is equated with purity and freedom-signaling civility- contends with Islamic norms of modesty, privacy, and purity (Ewing 2008).

It is clearly not the scarf itself, but rather the female Muslim body that is here "at issue" - "the body and its forces, their utility and their docility" (Foucault 1995 p. 25). The male Muslim body is also "at issue," in similar (fragmented by focusing on such markers as "the beard") and different (perceived as violently threatening both to mainstream society and to Muslim women) ways. Katherine Pratt Ewing traces the stigmatization of Muslim men in Berlin through imaginations, "social fantasies," that include embodied forms seen to signal danger (Ewing 2008, p. 180). This dualistic discourse of danger does more than stigmatize the male Muslim body, however. It also falsely externalizes hierarchical social relations, attempting to turn Islam on itself by painting the headscarf as a symbol of male domination over women. In so 
doing, it solidifies the broader social hierarchy across European states and societies, emplacing and sustaining the subordination of Muslim bodies.

The fixation on the Muslim body as incompatible with Europe emerged not only in my conversations with Muslims in Berlin, but also those with officers in the Neukölln police precinct, responsible for relations with the Şehitlik Mosque. Descriptions by two police officers in the precinct, Berat and Ateş, consistently painted "Muslim" dress, including prayer caps and Qur'ans in the hands of children, as potentially dangerous. Berat was himself raised in what he terms a "modern" Muslim family, while his colleague Ateş belongs to the Turkish Alevi religious minority. Throughout our conversation, Ateş described Berat as an ideal Muslim (that is, explicitly not religious), juxtaposed to his portrayals of the threat posed by visible Muslims.

A school child holding a Qur'an in his hand, reading it, it's like when a Christian holds the Bible and reads it. Well, it's seen differently, with the current politics in the world, it's put in another box. When there is a Muslim who now holds the Qur'an, or changes her clothing... one who dressed in a modern way puts on the headscarf for the first time, or the next level would be to go to the burqa, then you can't see anything. These are already indications for us that we need to see in which direction things go. -Ateş

Berat followed this anecdote by recounting the specific story of a male student who changed his dress, donning a prayer cap at school.

For example, there was a school child who was sixteen years old, for three to four months dressed very traditional...head covering, and wants his Qur'an with him...The parents don't know. The parents said in the beginning, "Oh great, he prays. He is no longer on the street. He has become believing." But they don't see in what direction he has developed. And one needs to trick him, when one speaks with this boy. When we speak with him, he has Qur'an experiences already, we also have Qur'an experience but we aren't believers. He might say, "You aren't believers, you play with [Islam]... Where is it in the school rules that I have to take off my hat? There is no school rule that I have to take off my hat." We say, "Ok that's true, you are right, but there is a school order...one takes off the hat out of respect." And then we ask, "Where is it in the Qur'an [to wear the hat]? When one goes to the mosque one takes off shoes. This is also not in the Qur'an but you do that also, because of respect and not to make it dirty." That was a good idea of ours and he accepted it.

That Berat took pride in "trick[ing]" a student by making spurious connections between an outwardly Muslim appearance and radicalism, citing Islamic traditions (here not wearing shoes in the mosque in order to keep it clean) exposes the deep cultural discourses that classify Muslim bodies as a polluting presence in civic life. By alluding to a prayer cap making the school "dirty," he powerfully exemplified how these discourses not only continue to frame, but also regulatein both everyday encounters, and mass surveillance by the security apparatusthe Muslim body as a subordinate, uncivil form. 
I have here focused on the coding of visible Muslim symbols with incivility, as part of a politics of divisibility, in which the Muslim body is divided from the larger social body in Germany. While these visible symbols of Islam are among the most virulently targeted, it is imperative to note that any markers of Muslimsness can lead to discrimination-in securing residences, as noted by Sadiye, education, employment, as well as mundane encounters in everyday life. Meral, for instance, reflected on her own experience with assumptions attached to her being Muslim after beginning law school:

I feel like we are still struggling with stereotypes, especially gender relations, what people think women are not allowed to do in Islam. I have an anecdote to tell. I had a German friend, we were close in fourth grade, then our school was closed. We got separated. I ran into her . . . She was shocked when I told her I was going to law school. "What are you going to law school for? You are not supposed to be going to law school..." That was her facial reaction.

When Selim, a history teacher in a Berlin public school, requested Fridays off to attend the Friday prayer each week the same spring, the principal not only refused but drew a line between him and Judeo-Christian civility. "This is not a religious school and you cannot indoctrinate students. You don't see Jewish and Christian people asking for this," she remarked. And when invited to talk about her profession in her daughter's kindergarten class in spring 2015, Ecrin, a young mother of three and mosque leader, asked to discuss her work in the mosque. "We don't educate children in religion. Religion has no place here," the teacher retorted. Together, these instances point to how the culturally subordinate position occupied by Muslims in public life, one juxtaposed to the secular and/or (Judeo-)Christian norm, is articulated and sustained across social realms.

\section{Undercaste: the institutionalization of incivility}

Emerging from these discursive and symbolic distinctions, the deep and lasting associations of Muslims with incivility have become broadly institutionalized across Europe in determinate spheres of social inclusion. This association has many consequences, not least of all heightened surveillance and imprisonment, as Muslims make up disproportionate and surging percentages of European penitentiary systems, but also ongoing exclusion across the economic, educational, residential, and private spheres. ${ }^{9}$ The following discussion of these marginalities on a broader level is far from comprehensive. Instead, it serves to provide a sketch of trends in marginalization and exclusion, from occupational subjugation to educational penalization, residential segregation and endogamy that result from this enduring uncivil status: a sketch of what it means to belong to Europe's undercaste.

\footnotetext{
9 In Britain, for instance, 16 percent of all prisoners are Muslims, increasing from 8 percent in 2002, a far greater increase than for any other group (Sturge 2020).
} 
Occupational subjugation began with the guest worker programs and migration of colonial subjects, recruited to fill labor shortages, working in mines, construction, and service. Migrants became relegated to the bottom not only of the economic but also social hierarchy, dehumanized, differentiation of "us" versus "them" embedded with notions of savagery: "the internal partition between humans and nonhumans ... through which the [so-called] moderns have set themselves apart from the [socalled] premoderns" (Latour 1993, p. 99). Treated like animals, former guest workers like my interlocutor, Mustafa, recounted their teeth being checked at the border, experiencing what Arendt terms only an "illusion of liberty and unchallenged humanity" (Arendt 1944, p. 121). Upon settlement in Germany, they were called Kanake, a derogatory term, which often means "wild man" in its origin language (Polynesian) (Stowasser 2002, p. 70). A documentary on postcolonial South Asian migration to the Midlands features a discontented white British interviewee echoing this sentiment: "They are content with Kitekat (cat food) and dog food instead of ordinary meat" (Woods 2016). Samia Fekih, a digital project manager in Paris, told the New York Times: "I was curious to see if, in the cities where they forbade women in burkinis, dogs could swim. The answer was yes for some of them . . dogs can have more rights than a scarfed woman" (Dremeaux 2016). Idealized "Euro-Islam," reforming and moderating religiosity, has tellingly been designated "domestication" in colloquial parlance across Europe (Laurence 2012, p. 11).

Employment opportunities have been affected by these perceptions of immutable difference. Statistical data starkly evidence that Muslims-irrespective of ethnic group or national status - not only have far lower labor market participation, but also experience significantly higher job refusal across Europe than non-Muslims (including those identifying with other religious groups). Matthias Koenig, Mieke Maliepaard, and Ayse Güveli (2016) find employment gaps between Muslim and Christian immigrants to Western Europe. Claire Adida, David Laitin, and MarieAnne Valfort (2010) have shown that a Muslim candidate is significantly less likely to be called back for a job interview than an African origin Christian in France; their research reveals that for every 100 positive responses to a job application under an African origin Christian name, an equivalent job application under a Muslim name receives only 38 positive responses. In 2015, Valfort (2015) conducted the largest experimental study to date measuring the effects of religion on hiring in France. In her study, practicing Muslims receive callbacks only half as often as practicing Catholics of the same ethnic background. In Germany, a study on internship applications shows that those with Turkish-sounding names receive fourteen percent fewer callbacks than those with German names (Kaas and Manger 2012). And Moroccan and Turkish Belgians experience an unemployment rate $(38 \%)$ more than five times the national average (7\%) (Open Society Foundations 2009, p. 111). While this is more notable in some country cases than others, Muslims throughout Europe remain not only significantly underemployed, but underrepresented in managerial and other well-paid positions. Pointedly overrepresented in the service industries, obstructions to labor mobility have continued to determine a subordinate position in the occupational hierarchy (Haug, Mussig, and Stitchs 2006). Labor market disadvantages persist even with high educational achievement and professional training (Peucker and Akbarzadeh 2014, p. 44). 
Labor market discrimination against Muslims has been documented by human and civil rights organizations as well as through limited academic study. In Belgium, a 2010 Amnesty International (2012, p. 33) study found that "Muslims filed 84 percent of the cases of religious discrimination collected by the Centre for Equal Opportunities," most often regarding women's dress or a failure to accommodate religious needs in the workplace. Explicit prohibition of religious symbols in public has been accompanied by relegation to back office positions in the private sector (Brems 2020, p. 88). A recent parliamentary report in the UK describes Muslim women as the single most disadvantaged group in the labor market, encountering a "triple penalty" on account of being Muslim, (usually) ethnic minorities, and female (Women Equalities Committee 2015, p. 15). And, according to the Equalities Review Commission in the UK (2007, p. 35), "more than two in three Bangladeshis and more than half of all Pakistanis live in the bottom decile for deprivation." The 2011 British census maps this economic deprivation, finding that " $46 \%$ (1.22 million) of the Muslim population resides in the $10 \%$ most deprived, and only $1.7 \%$ $(46,000)$ in the $10 \%$ least deprived local authority districts in England, based on the Index of Multiple Deprivation measure" (Ali 2015, p. 18).

The educational penalization of Muslims, in particular when wearing religious symbols, is also widespread. Those with migrant backgrounds in Germany are seriously overrepresented in vocational training schools and underrepresented in the high schools that feed into the university (Gymnasium), and thus underrepresented in universities (Luciak 2004, pp. 19-20). A recent study conducted by researchers at the University of Mannheim found that teachers grade students with migrant backgrounds worse than those without, in spite of equal performance levels (Bonefeld and Dickhäuser 2018). Much of the regulation in schools unsurprisingly relates to female dress. In Spain, in 2009, 37 percent of the populace believed girls wearing headscarves should be expelled from school, although no clear-cut regulation exists, with individual school boards determining the guidelines on worn religious symbols. In one case, a sixteen-year-old girl attending a public high school, Instituto Camilo José Cela de Pozuelo de Alarcón in Madrid, was banned from attending classes and forced to sit in the visitors' room when she refused to remove her headscarf in 2010 (Amnesty International 2012, pp. 70-71). In France, as noted above, the 1994 ban on religious garb in state schools singularly targeted the headscarf and not "discreet" symbols such as the Jewish kippah or the Christian cross; the so-called "headscarf debates" culminated in the outlawing of all conspicuous religious symbols in 2004, with Muslim girls inordinately targeted thereafter. For instance, the New York Times published a piece on a young girl from Charleville-Mézières, France, who was suspended twice for wearing not a headscarf but a long black skirt- "an ostentatious sign” of her religious belief in 2015 (Hamel 2002, pp. 297-298; Rubin 2015).

Interconnected with labor market discrimination and educational penalization, residential segregation has been an implicit reality for Muslims living in European cities since the first waves of postcolonial/guestworker migration over half a century ago. As Thomas Gieryn asserts, "place sustains difference and hierarchy" (Gieryn 2000 , p. 474). In the 1950s-1970s, guest workers lived only among each other in segregated housing units, reflecting expectations of temporary residence (Martin 1981). Today across Europe, many, like my interlocutor Sadiye, cannot access 
central housing on account of their "Muslim" names, relegated to the French banlieue or other doubly (socially and physically) marginalized areas across Europe, places_like Muslim bodies_associated with incivility (Slooter 2019). "The picture painted of Rosengard [Sweden] could just as well be that of any other stigmatized borough, suburb, or big city neighborhood such as Clichy-sous-Bois in Paris, Molenbeek in Brussels, or Tower Hamlets in London; these are the infamous "no go zones' for the average non-Muslim, white citizen," writes Per-Erik Nilsson (2018, p. 4). Muslims in the Netherlands overwhelmingly reside in neighborhoods with similarly weak infrastructure and crime (Stewart 2009, p. 7). In the UK, 28 percent of Muslims live in low-income social housing, and Tower Hamlets, the London borough with the highest percentage of Muslims, ranks among the most deprived local authority districts in all of England (Ali 2015, p. 19).

Finally, endogamy has long been studied as an indicator of social cleavages, a perception of difference that determines life choices not only in public, but in the more intimate private sphere (Gordon 1964; Chito Childs 2005; Alba and Foner 2015a, b; Alba and Foner 2015b). Some see endogamy as the "keystone of the caste system" (Davis, Gardner, and Gardner 2009, 44). Today, rates of intermarriage between Muslims and non-Muslims are notably low when compared to intermarriage between other groups (Lucassen and Laarman 2009; Alba and Foner 2015a,2015b). Viewed as an indicator of "social and cultural difference between immigrant groups and the native population," Lucassen and Laarman (2009, p. 54) find what they term "nonEuropean religion" (specifically, Islam or Hinduism) to be the most salient factor in deterring intermarriage (more so than race, ethnicity, colonial or guestworker heritage). Overall rates of intermarriage among predominantly Muslim groups in Europe range from $8-10 \%$ in contrast to $31-40 \%$ among predominantly non-Muslim groups with migration backgrounds. In the Netherlands, Surinamese and Antillean postcolonials are much more likely to be partnered with someone outside of their ethnic group than Turks or Moroccans (Kalmijn and van Tubergen 2006). Similarly, while Black Caribbean white partnerships have soared in the second generation, rates of intermarriage between second-generation Pakistani, Indian, as well as Bangladeshi and white Brits remain low (Equalities Review Commission 2007; Alba and Foner 2015a).

Together, these data reflect the experiences described by my interlocutors, who have faced subordination across all spheres of social life, similarly suggesting that Muslims in Europe experience a state of social distance and deprivation that results from their negatively coded cultural status: an enduring institutionalization of hierarchy based on an abstraction into a collective, uncivil other, rather than as distinct, individual citizens. I thus adamantly disagree with Rogers Brubaker's (2013, p. 5) claim that "Muslims in Europe are indeed deeply and multiply disadvantaged; but they are not disadvantaged, in the first instance, as Muslims." While there is no singular Muslim group in Europe, Muslims in Europe are very much disadvantaged as Muslims. This occurs not through their homogeneity nor self-identification as such, but rather the externally imposed classification of "Muslim" "as an amorphous, undifferentiated mass" by the societies in which they live (Rogozen-Soltar 2017, p. 12). The extent of social and economic deprivation of course differs both within and across country cases. However, the marking of Muslims with incivility; notable 
economic and education inequalities; and the persistence of high levels of residential segregation beyond the second generation together point to significant status-based social closure - not an underclass, but an undercaste.

\section{Discussion}

Framing Muslim positionality in Europe through caste makes possible a better understanding of both how and why enduring disadvantages are experienced by economically, racially, ethnically, and culturally diverse Muslim populaces across societies and across all realms of social life. Caste is the next step in moving from classor political status-based explanations to cultural status-based explanations, as class mobility and legal citizenship have not translated into the full inclusion of Muslims in Europe (Beaman 2017; Parvez 2017). Building on the important contributions made by scholars who have shown the powerful implications of cultural distinction through the concepts of Islamophobia and racialization/cultural racism, the concept of undercaste captures the specific othering of Muslims that fosters and upholds a hierarchical stratification system through associations with incivility- "Don't you see what Muslims do?!" It is distinctively able to demonstrate how shifting and knotted signifiers of Muslimness - relating to religion, ethnicity, race, and culturebecome used as "decoys" for systematic subordination (Wilkerson 2020, p. 18). As Gans (1996) and Wilkerson (2020, p. 18), I encourage the reader to think beyond the signifier or "decoy" (skin color, religion etc.) to this larger, hierarchical system based in cultural distinction.

Since this systematic cultural distinction entails a collapsing of religious, ethnic, racial, and cultural markers under the umbrella category of "Muslimness," distinction often functions in nuanced, implicit, ways. As Yusuf lucidly pointed out:

In Germany you don't have this borderline. There is no difference between Turkish and Muslim. There is no difference between, I don't know, Arab and Muslim. There is no difference between turban and Muslim. There is no difference between headscarf and Muslim. So it's really, they just look at you as different.

Some may argue that such differentiation relates primarily to ethnicity, or to perceived cultural "foreignness," but my interlocutors consistently described ethnic or cultural distinction as nested within a larger framework of Muslim distinction. For instance, they recounted how during the so-called refugee crisis faced by Germany in 2015, migrants were feared, and their potential integration questioned, as Muslims, just as ethnic Turks are feared, and their full societal participation questioned, as Muslims.

This experience is both unique to Muslims in Europe's postcolonial/postimperial age and also indicative of broader social tendencies in modern forms of cultural stratification. I have thus drawn parallels to the Jewish experience in Europe (as do both scholars of Muslim life in Europe, and Muslims in Europe, themselves) and the Black experience in the USA (Bodemann and Yurdakul 2005; Yurdakul 2006; Özyurek 2018). Yet the perceivable similarities between the 
ways in which Jewishness in Europe (from premodernity through the 20th century), and Blackness in the USA (from the 17th century to the present) have been constructed as uncivil cultural otherness tell us less about what European Jews, Black Americans, and European Muslims have in common than they do about the deeply discomforting realities of the societies in which we live. Simply put, framing the status of Muslims in Europe as an undercaste provides new ways of seeing the persistence and multidimensionality of culture-based status differentiation in modernity: with shifting target, but familiar form. It shows how groups become not "outcasts" (Wacquant 2006) but rather castes within.

Reinvigorating conceptualizations of caste also speaks to how we engage with and build upon existing sociological grammars. In his positing of the term undercaste, Gans (1996, p. 152) states that "the best terminological policy for social scientists is not to invent any new terms unless absolutely necessary, and to stay with very specific old ones whenever possible." This allows for disciplinary conversations to cross both geography and time, linking physically distant, but somehow similar social worlds (as in the cases of Black Americans, European Jews, and European Muslims), teaching us about how societies are organized, experienced, and lived. As part of a culturalist turn among social scientists theorizing Muslim marginalization in the West, Steve Garner and Saher Selod (2015) similarly argue that we should draw from existing sociological concepts to understand how social hierarchies are constructed and maintained across contexts. While they turn towards racialization to make sense of Muslim positionality in the US and UK-critiquing a predominantly black-white paradigm that has neglected immigrant groups in both-I highlight that sociological scholarship on Europe has unduly neglected caste in the study of Muslim marginality.

Aside from pointing out that caste boundaries are never completely closed, I have not engaged with the Indian caste system in this text. The motivation for this choice is twofold: (1) caste in India is both historically and contextually different from caste in Europe; and (2) my aim in this paper is not compare with-but rather to show the fruitfulness of considering how caste status functions beyondthe South Asian context. I will, below, suggest one productive parallel that can be seen in activities of resistance undertaken by collectivities of Muslims in Europe and Dalits in India. Here I would like to point out, however, that foremost sociologists of caste in India have also called for engagement with the concept beyond the geographical boundaries of South Asia, where it is often falsely relegated, as a broader "category of 'status' and 'power" undergirded by a "framework of prejudice and discrimination as a sociological process which enables and sustains [its] reproduction" (Jodhka 2016, p. 229). Surinder Jodhka (2016, p. 1), for instance, argues that its exoticization and thereby externalization from the Western context has "den[ied] the possibility of deploying the framework of caste for understanding caste-like ascriptive hierarchies that exist in many other (if not all) societies." His critique helps to answer the question of why, if the sociological concept of (under)caste fits the phenomenon at hand, it has not already emerged in scholarly conversations about Muslim positionality in today's Europe. It suggests that caste has gone unnoticed not only because of the dominance of materialist/class frameworks in the discipline, but also its associations with the very 
"Other" that the West defines itself against: as a "backward," "anti-liberal," even "uncivil" stratification system.

Employing the concept of caste, so often assumed to apply only outside of the Western context, and/or relegated to the cobwebbed sociological past, and bringing it to bear on current and enduring cultural exclusions in Europe, contends with assumptions about secularity and equality. It is-in the words spoken to me by Ebrahim Moosa, scholar of Islamic thought - an opportunity to "ask questions of unyielding certainties: certainties that are hollow." Such "hollow" certainties are implicit to the "Muslim question," around which so many debates over European societies are today framed: seen and heard in accusations of transgressive, uncivil difference in the possible shape of the modern European citizen, thereby threatening the social order. When these certainties are questioned, they reveal that the real threat is not Muslim incivility, but rather the exposure of civility's own shaky ground. Europe's self-juxtaposition to both Islam and Muslims reflects its own instability, and also its own incompleteness; as S. Sayyid (2006, p. 5) powerfully states, "the 'post' in postcolonial reminds us that we have not arrived at something that can have its own name." Thus, underneath the "Muslim question" lie unanswered, unsettling, questions about Europe itself: What and whose is Europe in this era where both pluralism and inequality reign? What and whose is Europe in this era with no name?

\section{Conclusion}

I would like to end on a note of resistance, rather than one of oppression. While agency has been largely absent from this paper, Muslim individuals and collectivities not only critically reflect upon, but critically act upon the marginality endowed by their undercaste status in Europe. As studies of India have shown, time and again, caste systems are not entirely closed, and both individual transgressions of, and collective organization against, caste boundaries occur (Desai and Dubey 2012; Chaudry 2019). Farhad Khosrokhavar (2019, p. 75) employs the term "subjectivation""the ability to empower oneself as a social actor"- to describe the means by which Muslims in Europe (and arguably marginalized populaces, more broadly) enact agency even under significant social constraints. That subjectivation, in its many forms, occurs through Islam-or at times, away from it, as I explain below-again highlights that neither a racial nor an ethnic boundary, but rather a boundary of "Muslimness" prevails in Europe, today (Khosrokhavar 2019, p. 75). As Hannah Arendt (1968, p. 18) powerfully asserts, one can "resist only in terms of the identity that is under attack."

Individually transgressing a caste boundary is one such form of resistance. This may be accomplished through the rejection of religious identity, often entailing an embrace of cultural liberalism, as with Neukölln police officer Berat. In this case, "Muslimness" is accepted as faulty and inferior to a secular European identity-paradoxically, if not tragically, reinforcing the very hierarchy one seeks to escape. Alternatively, the caste boundary can be individually transgressed through one's labeling as an "exceptional" Muslim, juxtaposed to most Muslims by the mainstream. Such 
exceptions do not dismantle systemic subordination, however, but again reinforce it, removing individuals from the uncivil Muslim undercaste, rather than incivility from its associations with Muslims (Mamdani 2002; Becker 2017). That is, persons may be accepted into the civil sphere, but not the broader polluted qualities of Muslimness (Alexander 2006). Such individual exceptionalism, in its juxtaposition to the collective, thus also helps to maintain the system of subordination. Michelle Alexander (2012, p. 248) makes this very argument regarding the prison industrial complex in the contemporary USA that relegates Black Americans to an undercaste status. "Highly visible examples of black success are critical to the maintenance of a racial caste system in the era of colorblindness. Black success stories lend credence to the notion that anyone, no matter how poor or how black you may be, can make it to the top, if only you try hard enough."

Muslims in Europe, however, also agentively respond to subordination as Muslims, that is without distancing themselves from other Muslims or "Muslimness" (Schiffauer 2004; Foroutan and Schäfer 2009; Ceylan 2017). I witnessed this form of subjectivation among the second and third generations of Şehitlik Mosque constituents, who represented their community as harmonized with German civic ideals like freedom and gender equality through high-profile events including the "My Head, My Choice" campaign (described below), and daily tours of the mosque. Subjectivation as Muslims also occurs in other European contexts and may take other formsspanning societal engagement and bridge-building, like the activism of the Harkis' daughters, also described below (Enjelvin and Korac-Kakabadse 2010); antipathy, as in the anti-politics that has emerged among some Muslims in French urban contexts- "as denigrated minorities" rejecting political engagement altogether (Parvez 2017 , p. 2); or even violent separatism, with extremism a powerful form of response to societal alienations and exclusions (Khosrokhavar 2019).

Allow me to return one final time to the Şehitlik Mosque community in Berlin where I carried out my research, and where such subjectivation was seen in response to limitations put on the Muslim woman's body in civic life. On July 14th, 2015, the "My Head, My Choice" campaign led protests against the banning of religious symbols in civil service positions in Berlin. Outside of Neukölln's city hall, children carried signs with the words spoken in unison by their mothers- "My head, my choice," "It matters what is in a woman's head, not what is on it," or "I am a Berliner"-printed beside sketches of women donning headscarves. Muslim and Jewish Berliners together developed this campaign, exemplifying the agentive refutation of Muslim incivility, after Betül, one of my interlocutors from Şehitlik quoted above, was denied a position in local government on account of her headscarf. Employing the language of liberal values, articulating the headscarf as a matter of individual autonomy and freedom, eventually led to a revocation of this decision; Betuil was regranted a position in city hall. She declined it.

Here a productive parallel can be made with the Dalit caste in India, also culturally marked as uncivil, which has increasingly collectively engaged with the state, countering caste-based violence and inequality through civility-based social movements. In his study of these movements, Suryakant Waghmore (2013) understands civility as providing emancipatory potential, reflecting the value of civility, as theorized by Edward Shils, as a connective social tradition (Boyd 1998). As the Durban 
Conference proceedings show, Dalit activists have employed not only a language of civility, but also that of civil rights, through race terminology: aiming to draw global attention to the ongoing human rights violations that they face (Visvanathan 2001). Collective action challenging an undercaste positionality today abounds in Europe as it does in India, with the "My Head, My Choice" campaign one among many instances in which those relegated to a subordinate position push back against social constraints. In both contexts, such campaigns - while not able to eliminate the caste status-illuminate how moral agency functions under constraints of discursive and material power, including how the very values of contemporary democracies can be used to confront their own normative shortcomings.

Another notable project of subjectivation undertaken by the children of Muslim immigrants is that of historical reckoning by the Harkis' daughters in France. Beginning in the early 2000s, Hadjila Kemoum, Zahia Rahmani, Dalila Kerchouche, and Fatima Besnaci-Lancou wrote texts situating the individual memories of their fathers within France's collective memory. Nested within a larger political movement to incorporate colonial histories into official national history, these emerged after then-President Jacques Chirac declared that "the Harkis are entirely French. They enjoy the respect and the recognition of the national community," soon after followed by the first official Harki Remembrance Day on September 25th, 2001 (Shepard 2006, p. 231). Before this, knowledge of the Harkis had remained largely relegated to family histories, a private, intergenerational reckoning with the dual rejection of the Harkis, as traitors by Algeria and as so-called "refugee" Muslims by France. Through these written acts of unsilencing personal histories, their daughters exposed the discrimination and scapegoating at the heart of the Harkis' experiences, as Muslims (Enjelvin and Korac-Kakabadse 2010, p. 155). Like the "My Head, My Choice" organizers, the Harkis' daughters questioned, and contended with, the caste boundary, based in incivility (in their case, a boundary that had migrated with their fathers from the colonial regime in French Algeria to contemporary France). They did so by addressing the endurance of subordination across both time and space, in the narrow understandings of Europe and European nation-states that have made a Muslim undercaste possible.

Acknowledgements I would like to thank my colleagues for their ongoing engagement with this text, which has been a work in progress for many years. I appreciate, in particular, the feedback from the Cultural Sociology workshop at Yale University and from the 2017 Council on European Studies Conference, as well as the close and critical readings by Julia Adams, Jeffrey Alexander, Shai Dromi, Phil Gorski, Jeanette Jouili, Tony Lin, Charles Mathewes, Armando Salvatore, Philip Smith, Sam Stabler, and Jonathan Wyrtzen. The research for the ethnographic piece of this article was generously funded by the NSF, the DAAD, the Fox Fellowship, and the Yale MacMillan Center.

Funding Open Access funding enabled and organized by Projekt DEAL.

Open Access This article is licensed under a Creative Commons Attribution 4.0 International License, which permits use, sharing, adaptation, distribution and reproduction in any medium or format, as long as you give appropriate credit to the original author(s) and the source, provide a link to the Creative Commons licence, and indicate if changes were made. The images or other third party material in this article are included in the article's Creative Commons licence, unless indicated otherwise in a credit line to the material. If material is not included in the article's Creative Commons licence and your intended use is not permitted by statutory regulation or exceeds the permitted use, you will need to obtain permission 
directly from the copyright holder. To view a copy of this licence, visit http://creativecommons.org/licen ses/by/4.0/.

\section{References}

Adida, C., D. Laitin, and M. Valfort. 2010. Identifying Barriers to Muslim Integration in France. Proceedings of the National Academy of Sciences 10 (52): 22384-22390.

Alba, R. 2005. Bright vs. Blurred Boundaries: Second-Generation Assimilation and Exclusion in France, Germany, and the United States. Ethnic and Racial Studies 28 (1): 20-49.

Alba, R., and N. Foner. 2015a. Strangers No More: Immigration and the Challenges of Integration in North America and Western Europe. Princeton, NJ: Princeton University Press.

Alba, R., and N. Foner. 2015b. Mixed Unions and Immigrant-Group Integration in North America and Western Europe. The ANNALS of the American Academy of Political and Social Science 662 (1): 38-56.

Alba, R., and M.C. Waters, eds. 2011. The Next Generation: Immigrant Youth in a Comparative Perspective. New York: NYU Press.

Alexander, J. 2003. The Meanings of Social Life: A Cultural Sociology. Oxford: Oxford University Press. Alexander, J. 2006. The Civil Sphere. Oxford: Oxford University Press.

Alexander, M. 2012. The New Jim Crow: Mass Incarceration in the Age of Colorblindness. New York: The New Press.

Ali, S. 2015. British Muslims in Numbers. London: Muslim Council of Britain. http://www.mcb.org.uk/ wp-content/uploads/2015/02/MCBCensusReport_2015.pdf.

Allen, C. 2005. From Race to Religion: The New Face of Discrimination. In Muslim Britain: Communities Under Pressure, ed. A. Tariq, 49-65. London: Zed Books.

Allievi, S. 2003. Konflikte um islamische Symbole in Europa. Journal Für Konflikt Und Gewaltforschung 5: 6-31.

Amin, A. 2010. The Remainders of Race. Theory, Culture \& Society 27 (1): 1-23.

Amir-Moazami, S. 2016a. Investigating the Secular Body: The Politics of the Male Circumcision Debate in Germany. ReOrient 1 (2): 147-170.

Amir-Moazami, S. 2016b. Dämonisierung und Einverleibung: Die ,muslimische Frage` in Europa. In Die Dämonisierung der Anderen. Rassismuskritik der Gegenwart, ed. M. CastroVarela and P. Mecheril. Bielefeld: Transcript Verlag.

Amnesty International. 2012. Choice and Prejudice: Discrimination Against Muslims in Europe. London: Amnesty International.

Arendt, H. 1944. The Jew as Pariah: A Hidden Tradition. Jewish Social Studies 6 (2): 99-122.

Arendt, H. 1968. Men in Dark Times. Boston: Houghton Mifflin Harcourt.

Arendt, H. 2007. The Jewish Writings. New York: Shocken Books.

Asad, T. 2002. Muslims and European Identity: Can Europe Represent Islam? In The Idea of Europe from Antiquity to the European Union, ed. A. Pagden, 209-227. Cambridge: Cambridge University Press.

Awan, I. 2012. I Am a Muslim Not an Extremist': How the Prevent Strategy Has Constructed a 'Suspect' Community. Politics \& Policy 40 (6): 1158-1185.

Baczynska, G., and S. Ledwith/. 2016. How Europe Builds Fences to Keep People Out. Huffington Post, 4 April, https://www.huffpost.com/entry/europe-refugee-fences_n_57026a49e4b083f5c6081121.

Badger, E. 2015. How the Rise of American-Style Segregation Is Feeding Division in Europe. Washington Post, 2 December, https://www.washingtonpost.com/news/wonk/wp/2015/12/02/how-the-riseof-american-style-segregation-is-feeding-division-in-europe/?utm_term=.891a1fa3 dbd 2 .

Balibar, É. 1991. Is There a 'Neo-racism'? In Race, Nation, Class: Ambiguous Identities, ed. É. Balibar and I. Wallerstein, 17-28. London and New York: Verso.

Bauman, Z. 1991. Modernity and Ambivalence. Cambridge: Polity Press.

Bayraklı, E., and F. Hafez. eds. 2016. European Islamophobia Report 2015. Istanbul: SETA Foundation for Politics, Economic and Social Research. https://setav.org/en/assets/uploads/2016/05/eir_2015. pdf 
Beaman, J. 2017. Citizen Outsider: Children of North African Immigrants in France. Berkeley: University of California Press.

Becker, E. 2017. Good Mosque, Bad Mosque: Boundaries to Belonging in Contemporary Germany. Journal of the American Academy of Religion 85 (4): 1050-1088.

Benhabib, S. 2000. The Reluctant Modernism of Hannah Arendt. Lanham, MD: Rowman \& Littlefield Publishers.

Berghahn, S. 2017. Die Kopftuchdebatte in Deutschland. In Rassismuskritik und Widerstandsformen, ed. K. Fereidooni and M. El, 193-212. Wiesbaden: Springer.

Berreman, G. 1960. Caste in India and the United States. American Journal of Sociology 66 (2): 120-127. Bhabha, H. 1985. Sly Civility. the MIT Press 34: 71-80.

Bhabha, H. 1994. The Location of Culture. Abingdon: Routledge.

Bleich, E. 2011. What Is Islamophobia and How Much Is There? Theorizing and Measuring an Emerging Comparative Concept. American Behavioral Scientist 55 (12): 1581-1600.

Bodemann, M., and G. Yurdakul. 2005. Geborgte Narrative: Wie sich türkische Einwanderer an den Juden in Deutschland orientieren. Soziale Welt 56: 441-451.

Bonefeld, M., and O. Dickhäuser. 2018. (Biased) Grading of Students' Performance: Students' Names, Performance Level, and Implicit Attitudes. Frontiers in Psychology 9 (481): 1-13.

Bougle, C. 1971. Essays on the Caste System. Cambridge: Cambridge University Press.

Bouie, J. 2015. Christian Soldiers. Slate Magazine, 10 February, https://slate.com/news-and-politics/ 2015/02/jim-crow-souths-lynching-of-blacks-and-christianity-the-terror-inflicted-by-whites-wasconsidered-a-religious-ritual.html

Boyd, R. 1998. Civility and Social Science: The Contribution of Edward Shils. Social Science Quarterly, 79(1), 242-249.

Boyd, R. 2006. The Value of Civility? Urban Studies 43 (5-6): 863-878.

Brah, A., M. Hickman, and M. Mac an Ghaill. 1999. Thinking Identities: Ethnicity, Racism and Culture. In Thinking Identities: Ethnicity, Racism and Culture, ed. A. Brah, M. Hockman, and M. Mac an Ghaill, 1-24. London: MacMillan Press.

Brems, E. 2020. Belgium: Discrimination against Muslims in Belgium. In State, Religion and Muslims: Between Discrimination and Protection at the Legislative, Executive and Judicial Levels, ed. M. Saral and S. Bahçecik, 65-108. Brill: Leiden.

Brubaker, R. 2013. Categories of Analysis and Categories of Practice: A Note on the Study of Muslims in European Countries of Immigration. Ethnic and Racial Studies 36 (1): 1-8.

Cakir, N. 2014. Islamfeindlichkeit: Anatomie eines Feindbildes in Deutschland. Bielefeld: Transcript Verlag.

Castles, S. 2006. Guestworkers in Europe: A Resurrection? International Migration Review 40: 741-766.

Ceylan, R. 2017. Islam und Muslime in Deutschland. Zeitschrift Für Religion, Gesellschaft Und Politik 1 (1): 75-88.

Chalmers, D. 1987. Hooded Americanism: The History of the Ku Klux Klan. Durham: Duke University Press.

Chaudhry, S. 2019. 'Flexible' Caste Boundaries: Cross-Regional Marriage as Mixed Marriage in Rural North India. Contemporary South Asia 27 (2): 214-228.

Chito Childs, E. 2005. Navigating Interracial Borders: Black-White Couples and their Social Worlds. New Brunswick, NJ: Rutgers University Press.

Christian, M. 2005. Class and Caste. In The Encyclopedia of Black Studies, ed. M. Asante and A. Mazama, 186-187. Thousand Oaks, CA: Sage.

Cooper, H. 2012. Controversial Dutch MP's Visa Bid Stalls. ABC, 18 September, https://www.abc.net.au/ news/2012-09-18/geert-wilders-applies-for-australian-visa/4268532.

Cue, E. 1994. For France, Girls in Head Scarves Threaten Secular Ideals. Christian Science Monitor, 5 October, https://www.csmonitor.com/1994/1005/05012.html.

Dagli, C. 2020. Muslims Are Not a Race. Renovatio, 6 February, https://renovatio.zaytuna.edu/article/ muslims-are-not-a-race.

Davis, B. 2011. Lifting the Veil: France's New Crusade. Comparative Law Review 34 (1): 117-145.

Davis, A., B. Gardner, and M. Gardner. 2009. Deep South: A Social Anthropological Study of Caste and Class. Columbia, SC: University of South Carolina Press.

Desai, S., and A. Dubey. 2012. Caste in 21st Century India: Competing Narratives. Economic and Political Weekly 46 (11): 40. 
Deutsche Welle. 2015. Survey Finds One in Three Germans Supports PEGIDA 'Anti-Islamicization' Marches, 1 January, https://www.dw.com/en/survey-finds-one-in-three-germans-supports-pegidaanti-islamization-marches/a-18166667.

Deutsche Welle. 2020. Berlin teacher headscarf ban is illegal, rules top court, 27 August, https://www.dw. com/en/berlin-teacher-headscarf-ban-is-illegal-rules-top-court/a-54722770

Dollard, J. 1937. Caste and Class in a Southern Town. New Haven, CT: Yale University Press.

Douglas, M. 1966. Purity and Danger: An Analysis of Concepts of Pollution and Taboo. Abingdon: Routledge.

Dremeaux, L. 2016. 'The Way People Look at Us Has Changed': Muslim Women on Life in Europe. New York Times, 2 September, https://www.nytimes.com/2016/09/03/world/europe/burkini-banmuslim-women.html.

Dumont, L. 1980. Homo Hierarchicus: The Caste System and Its Implications. Chicago: University of Chicago Press.

Eaude, M. 2008. Catalonia: A Cultural History. Oxford: Oxford University Press.

Elver, H. 2012. The Headscarf Controversy: Secularism and Freedom of Religion. Oxford: Oxford University Press.

Enjelvin, G., and N. Korac-Kakabadse. 2010. France and the Memories of 'Others': The Case of the Harkis. History and Memory 24 (1): 152-177.

Equalities Review Commission. 2007. Fairness and Freedom: The Final Report of the Equalities Review. Norwich: The Crown.

Ewing, Katherine Pratt. 2008. Stolen Honor: Stigmatizing Muslim Men in Berlin. Stanford: Stanford University Press.

Fassin, D. 2006. Nommer, interpréter: Le sens commun de la question raciale. In De la question sociale à la question raciale, ed. E. Fassin and D. Fassin, 19-36. Paris: La Découverte.

Fernando, M. 2014. The Republic Unsettled: Muslim French and the Contradictions of Secularism. Durham, NC: Duke University Press.

Foner, N. 2015. Is Islam in Western Europe Like Race in the United States? Sociological Forum 30 (4): 885-899.

Foner, N., and R. Alba. 2008. Immigrant Religion in the US and Western Europe: Bridge or Barrier to Inclusion? International Migration Review 42 (2): 360-392.

Foroutan, N., and S. Schäfer. 2009. Hybride Identitäten-muslimische Migrantinnen und Migranten in Deutschland und Europa. APuZ 5: 11-18.

Foucault, M. 1995. Discipline and Punish: The Birth of the Prison. New York: Vintage.

Fournier, P., and G. Yurdakul. 2010. Hinter dem Schleier: Zur sozialen Stellung muslimischer Frauen mit Kopftuch in Frankreich und Deutschland. In Staatsbürgerschaft, Migration und Minderheiten, ed. G. Yurdakul and M. Bodemann, 93-110. Wiesbaden: VS Verlag für Sozialwissenschaften.

Fox, J.W. 2007. Intimations of Citizenship: Repressions and Expressions of Equal Citizenship in the Era of Jim Crow. Howard Law Journal 50: 113-201.

Fraser, G. 2015. France's Much Vaunted Secularism Is Not the Neutral Space It Claims to Be. Guardian, 16 January, https://www.theguardian.com/commentisfree/belief/2015/jan/16/france-much-vauntedsecularism-not-neutral-space-claims-to-be.

Fredrickson, G. 2002. Racism: A Short History. Princeton, NJ: Princeton University Press.

Gallup. 2012. Islamophobia: Understanding Anti-Muslim Sentiment in the West. http://www.gallup.com/ poll/157082/islamophobia-understanding-anti-muslim-sentimentwest.aspx\#2.

Gans, H. 1996. From 'Underclass' to 'Undercaste': Some Observations About the Future of the Postindustrial Economy and Its Major Victims. In Urban Poverty and the Underclass: A Reader, ed. E. Mingione, 141-152. Cambridge, MA: Blackwell.

Garner, S., and S. Selod. 2015. The Racialization of Muslims: Empirical Studies of Islamophobia. Critical Sociology 41 (1): 9-19.

Gieryn, T. 2000. A Space for Place in Sociology. Annual Review of Sociology 26: 463-496.

Gordon, M. 1964. Assimilation in American Life. New York: Oxford University Pres.

Gümüsay, K. 2010. Mesut Özil ist Deutsch, ich bin es nicht. TAZ, 12 October, https://taz.de/KolumneDas-Tuch/!5134166/.

Hall, S. 2007. The West and the Rest: Discourse and Power. In Race and Racialization: Essential Readings, ed. T. Das Gupta, C. James, C. Anderson, G. Galbuzi, and R. Maaka, 56-64. Toronto: Canadian Scholars Press.

Hamel, C.E. 2002. Muslim Diaspora in Western Europe: The Islamic Headscarf (Hijab), the Media and Muslims' Integration in France. Citizenship Studies 6 (3): 293-308. 
Harris, E. 2007. Two Mosques, Two Different Reactions in Germany. NPR, 11 October. https://www.npr. org/templates/story/story.php?storyId=15043704.

Harvey, R. 2017. Luther and the Jews: Putting Right the Lies. Eugene, OR: Wipf and Stock Publishers.

Haug, S., Mussig, S. and Stichs, A. 2006. Muslim Life in Germany: A Study Conducted on Behalf of the German Conference on Islam. Federal Office for Migration and Refugees. http://www.npdata.be/ Data/Godsdienst/Duitsland/fb6-muslimisches-leben-englisch.pdf.

Higginbotham, M. 2013. Ghosts of Jim Crow: Ending Racism in Post-racial America. New York: NYU Press

Holston, J. 2010. The Civility of Inegalitarian Citizenships. In The Fundamentalist City? Religiosity and the Remaking of Urban Space, ed. N. AlSayyad and M. Massoumi, 51-71. Abingdon: Taylor and Francis.

Huggler, J. 2016. Germany's Far-Right AfD Party 'Has More Public Support than Ever.' Telegraph, 5 May, https://www.telegraph.co.uk/news/2016/05/05/germanys-far-right-afd-party-has-more-public-support-than-ever/.

Jodhka, S. 2016. Ascriptive Hierarchies: Caste and Its Reproduction in Contemporary India. Current Sociology 64 (2): 1-16.

Jones, N., and K. Braun. 2017. Secularism and State Neutrality: The Headscarf in French and German Public Schools. Australian Journal of Human Rights 23 (1): 61-89.

Joppke, C., and J. Torpey. 2013. Legal Integration of Islam: A Transnational Comparison. Cambridge, MA: Harvard University Press.

Jouili, J. 2015. Pious Practices and Secular Constraints: Women in the Islamic Revival in Europe. Stanford: Stanford University Press.

Kaas, L., and C. Manger. 2012. Ethnic Discrimination in Germany's Labour Market: A Field Experiment. German Economic Review 13 (1): 1-20.

Kalmijn, M., and F. Van Tubergen. 2006. Ethnic Intermarriage in the Netherlands: Confirmations and Refutations of Accepted Insights. European Journal of Population/revue Europeenne De Demographie 22 (4): 371-397.

Khosrokhavar, F. 2019. The Western Imaginary of Jihadism. Social Imaginaries 5 (2): 75-104.

Knowles, E. 2006. Pariah. In The Oxford Dictionary of Phrase and Fable, 2nd ed., ed. E. Knowles. Oxford: Oxford University Press.

Koenig, M., M. Maliepaard, and A. Güveli. 2016. Religion and New Immigrants' Labor Market Entry in Western Europe. Ethnicities 16 (2): 213-235.

Korteweg, A., and G. Yurdakul. 2014. The Headscarf Debates: Conflicts of National Belonging. Stanford: Stanford University Press.

Kouwer, B. 1949. Colors and Their Character: A Psychological Study. Dordrecht: Springer.

Latour, B. 1993. We Have Never Been Modern. Translated by C. Porter. Cambridge, MA: Harvard University Press.

Laurence, J. 2012. The Emancipation of Europe's Muslims. Princeton, NJ: Princeton University Press.

Lopez, F. 2011. Towards a Definition of Islamophobia: Approximations of the Early Twentieth Century. Ethnic and Racial Studies 34 (4): 556-573.

Löwenheim, O., and O. Gazit. 2009. Power and Examination: A Critique of Citizenship Tests. Security Dialogue 40 (2): 145-167.

Lucassen, L., and C. Laarman. 2009. Immigration, Intermarriage and the Changing face of Europe in the Post War Period. The History of the Family 14 (1): 52-68.

Luciak, M. 2004. Documenting Discrimination and Integration in 15 Member States of the European Union. Luxembourg: Office for Official Publications of the European Communities.

Malkiel, Y. 1948. Hispano-Arabic Marrano and Its Hispano-Latin Homophone. Journal of the American Oriental Society 68 (4): 175-184.

Mamdani, M. 2002. Good Muslim, Bad Muslim: A Political Perspective on Culture and Terrorism. American Anthropologist 104 (3): 766-775.

Martin, P. 1981. Germany's Guestworkers. Challenge 24 (3): 34-42.

Martínez, M.E. 2008. Genealogical Fictions: Limpieza de Sangre, Religion, and Gender in Colonial Mexico. Stanford: Stanford University Press.

McGraw, P. and J. Warner. 2012. The Danish Cartoon Crisis of 2005 and 2006: Ten Things You Didn't Know about the Original Muhammad Controversy. Huffington Post, 25 September, https://www. huffpost.com/entry/muhammad-cartoons_b_1907545.

Meer, N. 2013. Racialization and Religion: Race, Culture and Difference in the Study of Antisemitism and Islamophobia. Ethnic and Racial Studies 36 (3): 385-398. 
Meer, N. 2014. Key Concepts in Race and Ethnicity. London: Sage.

Meer, N., and T. Modood. 2009. Refutations of Racism in the 'Muslim Question.' Patterns of Prejudice 43 (3-4): 335-354.

Miles, R. 1989. Racism. London: Routledge.

Mocevic, N. 2020. Islam as Part of Europe. In Perspectives for Europe: Historical Concepts and Future Challenges, ed. M. Pausch, 45-60. Nomos: Baden-Baden.

Momigliano, A. 1980. A Note on Max Weber's Definition of Judaism as a Pariah-Religion. History and Theory 19 (3): 313-318.

Morrison, T. 1993. Nobel Lecture. Nobel Prize, 7 December, https://www.nobelprize.org/prizes/liter ature/1993/morrison/lecture/.

Nilsson, P.E. 2018. Open Source Jihad: Problematizing the Academic Discourse on Islamic Terrorism in Contemporary Europe. Cambridge: Cambridge University Press.

Nirenberg, D. 2016. Neighboring Faiths: Christianity, Islam, and Judaism in the Middle Ages and Today. Chicago: University of Chicago Press.

Norton, A. 2013. On the Muslim Question. Princeton, NJ: Princeton University Press.

Open Society Foundations. 2009. Muslims in Europe: A Report on 11 EU Cities. Open Society Foundations.

Özyürek, E. 2005. The Politics of Cultural Unification, Secularism, and the Place of Islam in the New Europe. American Ethnologist 32 (4): 509-512.

Özyürek, E. 2013. Creating Parallel Communities of Perpetrators: Muslim-Only Holocaust Education and Anti-Semitism Prevention Programs in Germany. Center for Jewish Studies, University of Illinois.

Özyürek, E. 2014. Being German, Becoming Muslim: Race, Religion, and Conversion in the New Europe. Princeton: Princeton University Press.

Özyürek, E. 2018. Rethinking Empathy: Emotions Triggered by the Holocaust Among the MuslimMinority in Germany. Anthropological Theory 18 (4): 456-477.

Parvez, F. 2017. Politicizing Islam: The Islamic Revival in France and India. Oxford: Oxford University Press.

Peucker, M., and S. Akbarzadeh. 2014. Muslim Active Citizenship in the West. Abingdon: Routledge.

Portes, A., and M. Zhou. 1993. The New Second Generation: Segmented Assimilation and its Variants among Post-1965 Immigrant Youth. Annals of the American Academy of Political and Social Science 530 (1): 74-98.

Postelnicesu, C. 2016. Europe's New Identity: The Refugee Crisis and the Rise of Nationalism. Europe's Journal of Psychology 12 (2): 203-209.

Poushter, J. 2016. European Opinions of the Refugee Crisis in 5 Charts. Pew Research Center (blog), 16 September, http://www.pewresearch.org/fact-tank/2016/09/16/european-opinions-of-the-refug ee-crisis-in-5-charts/.

Rana, J. 2007. The Story of Islamophobia. Souls 9 (2): 148-161.

Ravid, B. 1992. From Yellow to Red: On the Distinguishing Head-Covering of the Jews of Venice. Jewish History 6 (1/2): 179-210.

Rogozen-Soltar, M. 2017. Spain Unmoored: Migration, Conversion, and the Politics of Islam. Bloomington: Indiana University Press.

Roy, A. 2005. Civility and Empire: Literature and Culture in British India, 1822-1922. Abingdon: Routledge.

Rubin, A. 2015. French School Deems Teenager's Skirt an Illegal Display of Religion. New York Times, 29 April, https://www.nytimes.com/2015/04/30/world/europe/french-school-teenagers-skirt-illeg al-display-religion.html.

Said, E. 1979. Orientalism. New York: Vintage.

Salvatore, A. 2016. The Sociology of Islam. Leiden: Brill.

Saunders, P. 2006. Social Class and Stratification. Abingdon: Routledge.

Sayad, A. 2010. Immigration and 'State Thought.' In Selected Studies in International Migration and Immigrant Incorporation, ed. M. Martiniello and J. Rath, 165-180. Amsterdam: Amsterdam University Press.

Shepard, T. 2006. The Invention of Decolonization: The Algerian War and the Remaking of France. Ithaca: Cornell University Press.

Said, E. 1994. Culture and Imperialism. London: Vintage.

Sayyid, S. 2006. Introduction: Br Asians: Postcolonial People, Iconic Citizens. In Postcolonial People: South Asians in Britain, ed. N. Ali, S. Sayyid, and V.S. Kalra, 1-10. London: C. Hurst \& Co. 
Schiffauer, W. 2004. Vom Exil-zum Diaspora-Islam Muslimische Identitäten in Europa. Soziale Welt 55 (4): 347-368.

Schiffauer, W. 2006. Enemies within the Gates: The Debate about the Citizenship of Muslims in Germany. In Multiculturalism, Muslims and Citizenship: A European Approach, ed. T. Modood, A. Triandafyllidou, and R. Zapata-Barrero, 94-116. Abingdon: Routledge.

Scott, J.W. 1988. Deconstructing Equality-versus-Difference: Or, the Uses of Post-structuralist Theory for Feminism. Feminist Studies 14 (1): 33-50.

Scott, J.W. 2007. The Politics of the Veil. Princeton, NJ: Princeton University Press.

Sennett, R. 1994. Flesh and Stone: The Body and the City in Western Civilization. New York: W. W. Norton \& Company.

Shachar, I. 1974. The Judensau: A Medieval Anti-Jewish Motif and Its History. London: Warburg Institute.

Simonsen, K.B., and B. Bonikowski. 2020. Is Civic Nationalism Necessarily Inclusive? Conceptions of Nationhood and Anti-Muslim Attitudes in Europe. European Journal of Political Research 59 (1): $114-136$.

Slooter, L. 2019. The Making of the Banlieue: An Ethnography of Space, Identity and Violence. Cham: Springer.

Smale, A. 2016. Austria Rejects Far-Right Presidential Candidate Norbert Hofer. New York Times, 4 December, https://www.nytimes.com/2016/12/04/world/europe/norbert-hofer-austria-election.html.

Stanley-Becker, I. 2017. Marine Le Pen Falls Short in Far-Right Bid for the Presidency of France. Washington Post, 7 May, https://www.washingtonpost.com/world/europe/marine-le-pen-congratula tes-emmanuel-macron-on-his-victory-in-french-presidential-race/2017/05/07/afe9064e-3021-11e7a335-fa0ae1940305_story.html.

Stewart, F. 2009. A Global View of Horizontal Inequalities: Inequalities Experienced by Muslims Worldwide. SSRN Scholarly Paper. Rochester: Social Science Research Network, https://papers.ssrn. com/sol3/papers.cfm?abstract_id=1433779.

Stowasser, B. 2002. The Turks in Germany: From Sojourners to Citizens. In Muslims in the West: From Sojourners to Citizens, ed. Y. Haddad, 52-71. Oxford: Oxford University Press.

Sturge, G. 2020. Briefing Paper CBP-04334: UK Prison Population Statistics. House of Commons Library, https://commonslibrary.parliament.uk/research-briefings/sn04334/.

Taylor, G. 2017. Teachers' Religious Headscarves in German Constitutional Law. Oxford Journal of Law and Religion 6 (1): 93-111.

TellMAMA. 2016. Press. https://tellmamauk.org/press-section/.

The Telegraph. 2010. Marine Le Pen: Muslims in France 'like Nazi Occupation.' 12 December, https:// www.telegraph.co.uk/news/worldnews/europe/france/8197895/Marine-Le-Pen-Muslims-inFrance-like-Nazi-occupation.html.

Thomas, P. 2014. Prevent and Community Cohesion in Britain: The Worst of All Possible Worlds? In Counter Radicalisation: Critical Perspectives, ed. C. Baker-Beall, C. Heath-Kelly, and L. Jarvis, 36-53. Abingdon: Routledge.

Traverso, E. 1995. The Jews and Germany: From the "Judeo-German Symbiosis" to the Memory of Auschwitz. Lincoln, NE: University of Nebraska Press.

Valfort, M.A. 2015. Religious Discrimination in Access to Employment: A Reality. Paris: Institut Montaigne.

Van Bohemen, S., and R. Kemmers. 2011. Secular Intolerance in a Post-Christian Society: The Case of Islam in the Netherlands. In Paradoxes of Individualization: Social Control and Social Conflict in Contemporary Modernity, ed. D. Houtman, S. Aupers, and W. de Koster, 141-155. Surrey: Ashgate.

Visvanathan, S. 2001. The Race for Caste: Prolegomena to the Durban Conference. Economic and Political Weekly 36 (27): 2512-2516.

Wacquant, L. 2006. Urban Outcasts: A Comparative Sociology of Advanced Marginality. Cambridge: Polity Press.

Wacquant, L. 2007. French Working-Class Banlieues and Black American Ghetto: From Conflation to Comparison. Qui Parle 16 (2): 5-38.

Waghmore, S. 2013. Civility Against Caste: Dalit Politics and Citizenship in Western India. New Delhi: Sage Publications India.

Weber, M. 1946. Weber: Essays in Sociology. Oxford: Oxford University Press.

Weber, M. 2010. Ancient Judaism. New York: Simon and Schuster. 
Wike, R., S. Stokes, and B. Simmons. 2016. Europeans Fear Wave of Refugees Will Mean More Terrorism, Fewer Jobs. Pew Research Center, 11 July, https://www.pewresearch.org/global/2016/07/11/ europeans-fear-wave-of-refugees-will-mean-more-terrorism-fewer-jobs/.

Wilkerson, I. 2020. Caste: The Origins of Our Discontents. New York: Random House.

Wilson, N. 1978. Bernard-Lazare: Antisemitism and the Problem of Jewish Identity in Late NineteenthCentury France. Cambridge: Cambridge University Press.

Women Equalities Committee. 2015. Employment Opportunities for Muslims in the UK. House of Commons. https://publications.parliament.uk/pa/cm201617/cmselect/cmwomeq/89/89.pdf

Wood, A.L. 2011. Lynching and Spectacle: Witnessing Racial Violence in America, 1890-1940. Chapel Hill, NC: University of North Carolina Press.

Woods, R. 2016. England in 1966: Racism and Ignorance in the Midlands. BBC News, 1 June, https:// www.bbc.com/news/uk-england-birmingham-36388761.

Yeung, P. 2016. EU Referendum: Reports of Hate Crime Increase 57\% Following Brexit Vote. Independent, 27 June, https://www.independent.co.uk/news/uk/home-news/brexit-hate-crime-racism-repor ts-eu-referendum-latest-a7106116.html.

York, C. 2016. Post-Brexit Racism Documented on Social Media. Huffington Post, 2 July, https://www. huffingtonpost.co.uk/entry/post-brexit-racism_uk_5777be69e4b073366f0f1d06?guccounter=1\& guce_referrer=aHR0cHM6Ly9zZWFyY2gueWFob28uY29tLw\&guce_referrer_sig=AQAAA MEzpWAnxLvIt3XXILJAWHjcktw1Z4HGu9DM39Ddj30atx2N8ebIzP7700jxdRRI-pS9Wfk32jx XyAMfcBOmiKt52xfC91X4nusvpGg55P7CYm9ToCxS-ZFKbCY1Ryw4H8gIj16CtqnkvzZh6oD 1V8Lk-kl-6X9COAOlx815GEMo

Yurdakul, G. 2006. "We Don't Want To Be the Jews of Tomorrow": Jews and Turks in Germany after 9/11. German Politics and Society 24 (2): 44-67.

Yurdakul, G. 2016. Jews, Muslims and the Ritual Male Circumcision Debate: Religious Diversity and Social Inclusion in Germany. Social Inclusion 4 (2): 77-86.

Publisher's Note Springer Nature remains neutral with regard to jurisdictional claims in published maps and institutional affiliations.

Elisabeth Becker is a Freigeist Fellow (Assistant Professor) at the Max Weber Institute of Sociology, Heidelberg University. Her work centers on culture and religion/ethnicity/race-based inequality in the urban contexts of Europe and the USA. Her book Mosques in the Metropolis: Incivility, Caste, and Contention in Europe is forthcoming with University of Chicago Press. Her writing has appeared in numerous journals and edited volumes, including: the Journal of the American Academy of Religion, Ethnic \& Racial Studies, the Annual Review of Sociology, the International Journal for Islamic Architecture, the European Journal of Sociology, and the Annals of Tourism Research. 